\title{
LAS NORMAS DE COMPETENCIA INTERNACIONAL EN MATERIA DE RESPONSABILIDAD PARENTAL EN EL REGLAMENTO (UE) 2019/1111 DEL CONSEJO DE 25 DE JUNIO DE 2019
}

\author{
THE RULES ON INTERNATIONAL JURISDICTION \\ IN MATTERS OF PARENTAL RESPONSIBILITY IN COUNCIL \\ REGULATION (EU) 2019/1111 OF 25 JUNE 2019
}

\author{
Alicia Bernardo San José \\ Profesora Titular de Derecho Procesal \\ Universidad Complutense de Madrid
}

Recibido: 14.06.2020 / Aceptado: 03.07.2020

DOI: https://doi.org/10.20318/cdt.2020.5671

\begin{abstract}
Resumen: En este trabajo se efectúa un análisis de las normas de competencia judicial internacional en materia de responsabilidad parental del Reglamento (UE) 2019/1111 (Reglamento Bruselas II ter). Estas normas se examinan con el objetivo de detectar las modificaciones y mejoras introducidas por el legislador europeo en el nuevo Reglamento, en comparación con las normas del actual Reglamento (CE) $n^{\circ}$. 2201/2003 (Reglamento Bruselas II bis), que quedará derogado a partir del 1 de agosto de 2022. Se realiza, además, un estudio exhaustivo de la jurisprudencia del Tribunal de Justicia de la Unión Europea acerca del sentido en que deben interpretarse las normas de competencia a efectos del RB II bis, y su aplicabilidad al RB II ter.
\end{abstract}

Palabras clave: competencia judicial; responsabilidad parental; interés superior del menor; residencia habitual; forum non conveniens.

Abstract: This paper analyzes the rules of international jurisdiction on parental responsibility in the Council Regulation (EU) 2019/111 (Brussels II ter Regulation). These rules are examined with a view to identifying the amendments and improvements introduced by the European legislator to the new Regulation, as compared to the rules of the current Council Regulation (EC) $n^{\circ}$ 2201/2003 (Brussels II bis Regulation), which will be repealed from 1 August 2022. In addition, a comprehensive study is carried out on the jurisprudence of the European Court of Justice on how the jurisdiction rules must be interpreted within the meaning of BR II bis and their applicability to BR II ter.

Keywords: international jurisdiction; parental responsibility; best interests of the child; habitual residence; forum non conveniens.

Sumario: I. Introducción. II. Breve referencia al ámbito de aplicación del RB II ter. III. El concepto de responsabilidad parental según el RB II ter. IV. La materia de responsabilidad parental a la luz de la jurisprudencia del TJUE. 1. Decisión relativa a la guarda de menores y a su acogimiento

\footnotetext{
*Este trabajo fue preparado para ser defendido en el Seminario «Hacia un proceso civil convergente con Europa: balance de situación», dirigido por los Profs. Fernando Gascón Inchausti y Pilar Peiteado Mariscal, que debería haberse celebrado en la Facultad de Derecho de la UCM el 25 de junio de 2020 y que tuvo que ser suspendido como consecuencia de la pandemia asociada al Covid-19. Es uno de los resultados del proyecto de investigación "Hacia un proceso civil convergente con Europa. Hitos presentes y retos futuros" (PGC2018-094693-B-I00), financiado por el Ministerio de Ciencia e Innovación.
} 
fuera del domicilio familiar. 2. Medidas de protección de menores regidas por el Derecho público. 3. Acogimiento en régimen cerrado en un establecimiento. 4. Aprobación de un acuerdo de reparto sucesorio concluido por el tutor. 5. Viaje de un menor fuera del Estado en que reside y expedición de un pasaporte a su nombre. 6. Autorización para repudiar la herencia del abuelo presentada por los progenitores del menor. 7. Derecho de visita de los abuelos. V. La competencia judicial internacional en materia de responsabilidad parental en el RB II ter. 1. La residencia habitual del menor en un Estado miembro como criterio de aplicación del RB II ter. 2. El interés superior del menor. 3. El sistema de fueros del RB II ter. A) El fuero general: la residencia habitual del menor. B) Concepto de residencia habitual del menor a la luz de la jurisprudencia del TJUE: a) Integración del menor en un entorno social y familiar; b) Duración de la estancia; c) La edad del menor: concepto de residencia habitual de un menor lactante: d) Presencia física del menor; e) La intención de los padres de establecerse con el menor en un Estado miembro; f) Prevalencia de las consideraciones objetivas sobre los vínculos de carácter cultural del menor respecto a un Estado miembro y su nacionalidad. C) Los demás fueros del RB II ter: a) Mantenimiento de la competencia en relación con los derechos de visita; b) Competencia en caso de traslado o retención ilícitos de un menor; c) Elección del órgano jurisdiccional; d) Competencia basada en la presencia del menor; e) Competencia residual. 4. Remisión de competencia a un órgano jurisdiccional de otro Estado miembro mejor situado para valorar el interés superior del menor (forum non conveniens). A) Vinculación estrecha del menor con el órgano jurisdiccional del otro Estado miembro. B) Mejor situación del órgano jurisdiccional del otro Estado miembro para valorar el interés superior del menor. C) La remisión de competencia ha de responder al interés superior del menor. D) Procedimiento. E) Prohibición de remisión en caso de competencia exclusiva. 5. Transferencia de competencia solicitada por un órgano jurisdiccional de un Estado miembro que no tenga competencia. 6. Competencia para adoptar medidas provisionales, incluidas las cautelares, en casos de urgencia. 7. Competencia para conocer de cuestiones incidentales relacionadas con la responsabilidad parental. 8. Comprobación de la competencia. VI. Conclusión.

\section{Introducción}

1. A partir del 1 de agosto de 2022 se aplicará el Reglamento (UE) 2019/1111 del Consejo, de 25 de junio de 2019, relativo a la competencia, el reconocimiento y la ejecución de resoluciones en materia matrimonial y de responsabilidad parental, y sobre la sustracción internacional de menores, ya conocido como Reglamento Bruselas II ter (RB II ter, en lo sucesivo) ${ }^{1}$, y constituirá desde ese momento la piedra angular de la cooperación judicial de la Unión Europea en materia de Derecho de familia. El RB II ter será de aplicación en todos los Estados miembros de la Unión Europea, con la única excepción de Dinamarca.

2. Este nuevo instrumento jurídico de la Unión conlleva la derogación del Reglamento (CE) $n^{\circ}$. 2201/2003 del Consejo, de 27 de noviembre, relativo a la competencia, el reconocimiento y la ejecución de resoluciones judiciales en materia matrimonial y de responsabilidad parental, conocido como Reglamento Bruselas II bis, (RB II bis, en lo sucesivo), directamente aplicable y vinculante en los Estados miembros -salvo Dinamarca- desde hace ya más de quince años ${ }^{2}$.

3. Aunque el RB II bis está funcionando en términos generales satisfactoriamente y ha aportado a los ciudadanos beneficios importantes, desde hace ya algunos años los datos y las opiniones de los expertos han puesto de relieve algunas lagunas y deficiencias en su funcionamiento actual que conviene subsanar, tal y como ya recogía la Comisión en su Informe de 15 de abril de $2014^{3}$. Entre los dos ámbitos

\footnotetext{
${ }^{1}$ Los artículos 92 y 93 del Reglamento, sobre la facultad de la Comisión para adoptar actos delegados, y el artículo 103, sobre la información que deben comunicar los Estados miembros a la Comisión son aplicables desde el pasado 22 de julio de 2019.

${ }^{2}$ Con la aplicación del RB II ter, las referencias al Reglamento derogado se entenderán hechas al nuevo Reglamento y deberán interpretarse según la tabla de correspondencias que figura en el Anexo X (art. 104.2 RB II ter).

${ }^{3}$ Informe de la Comisión al Parlamento Europeo, al Consejo y al Comité Económico y Social Europeo sobre la aplicación del Reglamento (CE) $n^{\circ}$. 2201/2003 del Consejo relativo a la competencia, el reconocimiento y la ejecución de resoluciones judiciales en materia matrimonial y de responsabilidad parental, por el que se deroga el Reglamento (CE) $n^{\circ} 1347 / 2000$ (Bruselas, 15.4.2014, COM (2014) 225 final).
} 
cubiertos por el RB II bis, materia matrimonial y responsabilidad parental, parece que es en esta última materia donde se plantean graves problemas que es necesario abordar urgentemente ${ }^{4}$.

4. Dado que debe ser objeto de varias modificaciones, el legislador europeo ha considerado adecuado, en aras de la claridad, refundir dicho Reglamento. El objetivo de la refundición no es otro que seguir desarrollando el espacio europeo de justicia y derechos fundamentales basado en la confianza mutua, suprimiendo los obstáculos que subsisten a la libre circulación de las resoluciones, en consonancia con el principio de reconocimiento mutuo, así como proteger mejor el interés superior del menor mediante la simplificación de los procedimientos y la mejora de su eficacia.

5. Además, durante estos más de quince años de vigencia del RB II bis, el Tribunal de Justicia de la Unión Europea (TJUE, en lo sucesivo), como tribunal garante de la interpretación uniforme de las normas comunitarias ex art. 267 TFUE (antiguo art. 234 TCE), ha dictado numerosas resoluciones sobre el sentido en que han de interpretarse las normas del RB II bis, y resulta aconsejable incorporar la doctrina jurisprudencial a la nueva norma europea.

6. El RB II ter establece normas uniformes de competencia relativas al divorcio, la separación legal y la nulidad matrimonial, así como a los litigios sobre responsabilidad parental en situaciones transfronterizas. Facilita la libre circulación de las resoluciones, los documentos públicos y los acuerdos en la Unión, al establecer disposiciones relativas a su reconocimiento y ejecución en otros Estados miembros. Contiene, además, disposiciones que complementan el Convenio de La Haya de 25 de octubre de 1980, sobre los aspectos civiles de la sustracción internacional de menores, en lo referente a las relaciones entre Estados miembros. Por consiguiente, este Reglamento debe contribuir a reforzar la seguridad jurídica e incrementar la flexibilidad, y a garantizar un mejor acceso a los procesos judiciales y una mayor eficacia de dichos procesos ${ }^{5}$.

7. En este primer trabajo sobre el RB II ter no pretendo analizar el Reglamento en su integridad, antes bien, voy a limitar doblemente su objeto. Por un lado, me centraré en el estudio de las normas de competencia judicial, dejando al margen, por tanto, las de reconocimiento y ejecución y, por otro lado, ceñiré el estudio de estas normas a la materia de responsabilidad parental, excluyendo la materia matrimonial y la sustracción internacional de menores, salvo las referencias que sean inevitables. Estas normas se examinan con el propósito de detectar las modificaciones introducidas en esta materia por el legislador europeo y así, poder comprobar en qué medida se mejora la normativa vigente. Se efectúa, además, un estudio exhaustivo de la jurisprudencia del TJUE durante la vigencia del RB II bis para conocer de qué modo ha sido incorporada al texto del nuevo Reglamento.

\section{Breve referencia al ámbito de aplicación del RB II ter}

8. Respecto del ámbito de aplicación del RB II ter hay que distinguir los siguientes aspectos: territorial o espacial, temporal y material.

9. En cuanto al ámbito territorial, el RB II ter se aplicará en todos los Estados miembros de la Unión Europea, excepto Dinamarca. La excepción de Dinamarca proviene de las reservas efectuadas por este Estado mediante Protocolo (hoy, Protocolo ${ }^{\circ} 22$ TFUE sobre la posición de Dinamarca), por las que Dinamarca se desvinculaba de la "comunitarización" del "espacio de libertad, seguridad y justicia" del Título V de la Tercera Parte del TFUÉ.

\footnotetext{
${ }^{4}$ Para un examen de las seis cuestiones principales que, según el informe de la Comisión, era preciso abordar, vid. E. RoDRÍGUez PINAU, "La refundición del Reglamento Bruselas II bis: de nuevo sobre la función del Derecho internacional privado europeo", Revista Española de Derecho Internacional, Sección ESTUDIOS, Vol. 69/1, enero-junio 2017, Madrid, pp. 139-165.

${ }^{5}$ Cfr. Considerando 2 RB II ter.

${ }^{6}$ Cfr. Considerando 96 RB II ter.
} 
10. El RB II ter sí se aplicará en Irlanda. Reino Unido e Irlanda no participan plenamente en la "comunitarización" del espacio único de justicia y, en la actualidad, su posición respecto de esta materia se encuentra recogida en el Protocolo n ${ }^{\circ} 21$ TFUE. Estos Estados, no obstante, se reservaron la oportunidad de comunicar caso por caso su participación en los instrumentos comunitarios y, en efecto, comunicaron su voluntad de participar en la adopción y aplicación del presente Reglamento ("opting in") ${ }^{7}$. No obstante, como es sabido, el 31 de enero de 2020, el Reino Unido salió de la Unión Europea y dejó de ser "Estado miembro", por lo que desde esa fecha dejó de estar incluido en el ámbito espacial de aplicación de los instrumentos jurídicos de la Unión Europea en general y del RB II ter en particular8.

11. Por lo que se refiere al elemento temporal, la disposición transitoria primera (art. 100.1 RB II ter), señala expresamente que el presente Reglamento solo se aplicará "a los procedimientos incoados, a los documentos públicos formalizados o registrados y a los acuerdos registrados el 1 de agosto de 2022 o después de esa fecha". Por tanto, en relación con la materia que nos ocupa, desde esa fecha, la determinación de la competencia judicial internacional en materia de responsabilidad parental de los órganos jurisdiccionales de los Estados miembros de la Unión Europea se regirá por los fueros del RB II ter.

12. En materia de reconocimiento y ejecución, la disposición transitoria segunda (art. 100.2 RB II ter), matiza que el RB II bis seguirá aplicándose a "las resoluciones dictadas en procedimientos ya incoados, los documentos públicos formalizados o registrados y los acuerdos que hayan adquirido fuerza ejecutiva en el Estado miembro en el que hayan sido celebrados antes del 1 de agosto de 2022 y que entren dentro del ámbito de aplicación de dicho Reglamento".

13. El primero de los artículos del RB II ter regula su ámbito material de aplicación, en un doble sentido, positivo y negativo. En sentido positivo, el apartado 1 del art. 1 RB II ter establece que el presente Reglamento se aplica a las materias civiles relativas: a) al divorcio, la separación legal y la nulidad matrimonial; b) a la atribución, el ejercicio, la delegación, la restricción o la finalización de la responsabilidad parental. En su apartado 3, este mismo artículo señala que los capítulos III y IV del Reglamento relativos a la sustracción internacional de menores y al reconocimiento y ejecución, respectivamente, se aplican en casos de traslado o retención ilícitos de un menor que afecten a más de un Estado miembro, completando la regulación del Convenio de La Haya de 1980 sobre los Aspectos Civiles de la Sustracción Internacional de Menores. Y añade que el capítulo IV se aplica a resoluciones que ordenen la restitución de un menor a otro Estado miembro de conformidad con el Convenio de La Haya de 1980 que deban der ejecutadas en un Estado miembro distinto del Estado miembro donde se dictó la resolución.

14. En sentido negativo, el apartado 4 del art. 1 RB II ter establece que el Reglamento no se aplica: a) a la determinación y a la impugnación de la filiación; b) a las resoluciones sobre adopción y medidas que la preparan, ni a la anulación y revocación de la adopción; c) al nombre y apellidos del menor; a la emancipación; e) a las obligaciones de alimentos; f) a los fideicomisos y las sucesiones; g) a las medidas adoptadas a consecuencia de infracciones del Derecho Penal cometidas por los menores.

15. Sin duda, cada una de las materias incluidas positivamente en el ámbito de aplicación del Reglamento, así como las exclusiones ratione materiae, merecen un examen individualizado. No obstante, comoquiera que el presente trabajo tiene intencionadamente un objeto limitado a las normas de

\footnotetext{
${ }^{7}$ Cfr. Considerando 95 RB II ter.

${ }^{8}$ Sobre la salida del Reino Unido de la Unión Europea, véase el "Acuerdo sobre la retirada del Reino Unido de Gran Bretaña e Irlanda del Norte de la Unión Europea y de la Comunidad Europea de la Energía Atómica”, firmado en Bruselas y Londres el día 24 de enero de 2020, publicado el 31 de enero de 2020 en el Diario Oficial de la Unión Europea, y que entró en vigor el 1 de febrero de 2020. El art. 126 del Acuerdo establece un periodo transitorio o de ejecución que, en principio, finalizará el 31 de diciembre de 2020. El art. 132 dispone que, no obstante lo dispuesto en el art. 126, el Comité Mixto, antes del 1 de julio de 2020, podrá adoptar una decisión única por la que se prorrogue el periodo transitorio hasta un máximo de uno o dos años (vid., en especial, el Título VI del Acuerdo, relativo a la "cooperación judicial en curso en materia civil y mercantil”).
} 
competencia judicial del Reglamento en materia de responsabilidad parental, en las páginas que siguen me voy a centrar únicamente en esta materia.

\section{EI concepto de responsabilidad parental según el RB II ter}

16. El art. 1.1.b) RB II ter incluye la responsabilidad parental en el ámbito material de aplicación del Reglamento. En concreto, según este precepto, el Reglamento se aplica a todos aquellos asuntos que se refieran a "la atribución, el ejercicio, la delegación, la restricción o la finalización de la responsabilidad parental".

17. $Y$ es el propio Reglamento, en su art. 2.2.7), el que define la "responsabilidad parental" como el conjunto de "derechos y obligaciones conferidos a una persona física o jurídica en virtud de una resolución, por ministerio de la ley o por un acuerdo con efectos jurídicos, en relación con la persona o los bienes de un menor, incluidos, en particular, los derechos de custodia y visita".

18. El término "responsabilidad parental" ha sido y sigue siendo el elegido por el legislador europeo para referirse a los derechos y obligaciones que les corresponden a los progenitores sobre la persona y bienes de sus hijos (cfr. RB II y RB II bis). Se trata de un término más amplio que el de "patria potestad" -que aún utiliza nuestro Código Civil-, y desprovisto de cualquier sesgo patriarcal'. El vocablo "potestad" se vincula con el poder que evoca a la potestas del Derecho romano, centrado en la idea de dependencia absoluta del niño en una estructura familiar jerarquizada. Por el contrario, el empleo de la expresión "responsabilidad parental" implica el ejercicio de una función propia de ambos progenitores que se manifiesta en un conjunto de derechos y deberes dirigidos, primordialmente, a satisfacer el interés superior del niño.

19. Nótese, además, que en el concepto de "responsabilidad parental" del Reglamento no solo están comprendidos los progenitores del menor sino cualquier otra persona física o jurídica a la que se le hayan conferido derechos y obligaciones en relación con la persona o bienes del menor. Así, a los efectos del presente Reglamento, se entenderá por "titular de la responsabilidad parental" a cualquier persona, institución u organismo que tenga la responsabilidad parental sobre un menor (art. 2.2.8 RB II ter).

20. La aplicación de las normas en materia de responsabilidad parental se produce con frecuencia en el marco de un proceso matrimonial, de ahí que resulte adecuado contar con un único instrumento jurídico europeo aplicable a las dos materias, la matrimonial y la de responsabilidad parental. Ahora bien, con la finalidad de asegurar la igualdad de todos los menores, estén sus padres casados o no lo estén, el RB II ter se aplica a todas las medidas y resoluciones en materia de responsabilidad parental, incluidas las medidas de protección del menor, con independencia de que estas medidas y resoluciones estén vinculadas o no a un procedimiento matrimonial ${ }^{10}$.

21. El RB II ter, a diferencia del RB II bis ${ }^{11}$, define el concepto de "menor" como toda persona que tenga menos de 18 años (art. 2.2.6), coincidiendo así con el ámbito de aplicación del otro instrumen-

\footnotetext{
${ }^{9}$ El término "patria potestad" marca una época con un modelo de familia patriarcal que en la actualidad ha caído en desuso y ha sido reemplazado por un modelo de familia comunicativo y cooperativo. En consecuencia, esto ha llevado a que las legislaciones de muchos países reemplacen la expresión "patria potestad" por "responsabilidad parental" para referirse a los derechos y deberes entre padres e hijos.

${ }^{10}$ Cfr. Considerandos 7 y 8 RB II ter. Téngase en cuenta que en las dos últimas décadas la tasa de hijos nacidos fuera del matrimonio ha aumentado considerablemente en todos los Estados miembros de la Unión Europea. Según los datos publicados por la Oficina estadística europea (Eurostat), existe una tendencia cada vez mayor en toda la Unión Europea de nacimientos fuera del matrimonio. En 2018, la tasa de mujeres europeas que tuvieron hijos sin estar casadas con su pareja llegaba ya al $43 \%$, lo que permite hablar claramente de "un cambio de patrones" en el modelo de familia europeo. Los números apuntan a que, en unos años, más de la mitad de los recién nacidos tendrán padres y madres no casados.

${ }^{11}$ El RB II bis no dice qué se entiende por “menor”, por lo que hay que estar a la legislación nacional de cada Estado miembro.
} 
to legal internacional en materia de protección de los niños, el Convenio de La Haya de $1996^{12}$, que "se aplica a los niños a partir de su nacimiento y hasta que alcancen la edad de 18 años" (art. 2) ${ }^{13}$.

22. Hay que señalar, además, que el propio RB II ter, en su considerando 17, especifica que debe aplicarse a todos los menores de 18 años, aunque la persona antes de esa edad haya adquirido plena capacidad de obrar en virtud de su ley personal (por ejemplo, porque está emancipada por matrimonio) ${ }^{14}$. Esto evita toda posible superposición o colisión con el ámbito de aplicación del Convenio de La Haya de 13 de enero de 2000 sobre Protección Internacional de los Adultos, que se aplica a partir de los 18, y al mismo tiempo, evita lagunas entre los dos instrumentos. En el caso de los menores hasta 16 años, debe seguir aplicándose el Convenio de La Haya de 1980 y, por tanto, también el Capítulo III del RB II ter sobre la sustracción internacional de menores, que complementa la aplicación del Convenio de La Haya de 1980 en las relaciones entre los Estados miembros, de conformidad con el art. 1.3 RB II ter.

23. El RB II ter, en el apartado 2 del art. 1, señala expresamente algunas de las materias que pueden englobarse en la responsabilidad parental, cuya inclusión en el ámbito material del Reglamento no resulta cuestionable. En concreto, enumera las siguientes:

a) El derecho de custodia y el derecho de visita

24. Según el art. 2.2.9) RB II ter, el derecho de custodia "incluye los derechos y obligaciones relativos al cuidado de la persona de un menor y, en particular, el derecho a decidir sobre su lugar de residencia". Este último derecho tiene una enorme importancia, toda vez que, como se verá después, las normas de competencia del Reglamento se articulan alrededor de la residencia habitual del menor. Y el derecho de visita comprende, de conformidad con el art. 2.2.10) RB II ter, "los derechos de visita, incluido el derecho de llevar a un menor a otro lugar diferente al de su residencia habitual por un periodo de tiempo limitado".

b) La tutela, la curatela y otras instituciones análogas

25. Quedan comprendidas en la materia de responsabilidad parental las instituciones propias de guarda y protección legal de la persona y/o los bienes de los menores como la tutela, la curatela u otras instituciones protectoras similares (p. ej. en nuestro ordenamiento, el defensor judicial y la guarda de hecho).

c) La designación y las funciones de toda persona u organismo encargado de ocuparse de la persona o de los bienes de un menor, de representarlo o de prestarle asistencia

\footnotetext{
${ }^{12}$ Convenio de 19 de octubre de 1996 Relativo a la Competencia, la Ley Aplicable, el Reconocimiento, la Ejecución y la Cooperación en materia de Responsabilidad Parental y de Medidas de Protección de los Niños.

${ }^{13}$ Un interesante análisis sobre las modificaciones que se introducen en el RB II ter para mejorar las relaciones con el Convenio de La Haya de 1996, puede verse en B. CAmpuzano Díaz, "El nuevo Reglamento (UE) 2019/1111: análisis de las mejoras en las relaciones con el Convenio de La Haya de 19 de octubre de 1996 sobre responsabilidad parental", Cuadernos de Derecho Transnacional (Marzo 2020), Vol. 12, № 1, pp. 97-117.

${ }^{14}$ En este punto, el RB II ter se aparta del RB II bis, en el que no se hace ninguna referencia a los menores emancipados, y de la Guía práctica para la aplicación del Reglamento Bruselas II bis elaborada por la Comisión Europea en 2015, en la que expresamente se dice que las resoluciones dictadas respecto de los menores emancipados no se consideran en principio materia de responsabilidad parental y, por tanto, no entran en el ámbito de aplicación del Reglamento. A mi juicio, la aplicación del Reglamento a menores emancipados se compadece mejor con el principio del "interés superior del menor" que ha de informar cualquier interpretación y aplicación de las normas en esta materia, por lo que hay que celebrar la decisión del legislador europeo de incluirlos en el ámbito de aplicación del Reglamento En este sentido ya se ha manifestado P. OREJUdo PRIETO DE LOS Mozos, "Diez años de aplicación e interpretación del Reglamento Bruselas II bis sobre crisis matrimoniales y responsabilidad parental (análisis de los aspectos de competencia judicial internacional”, La ley. Unión Europea, núm. 21, 2014, p. 9.
} 
d) El acogimiento de un menor en un establecimiento o un hogar de acogida

26. El ámbito de aplicación del Reglamento incluye cualquier tipo de acogimiento del menor en un hogar de acogida, por una o más personas, o en una institución (p. ej. un orfanato o un centro de acogida de menores). También, el acogimiento con vistas a la adopción o el acogimiento por un progenitor o, cuando corresponda, por cualquier otro pariente cercano, así como los "acogimientos educativos" ordenados por un órgano jurisdiccional o concertados por una autoridad competente con el acuerdo de los progenitores del menor o a petición de estos como consecuencia de un comportamiento anómalo del menor. Sólo quedan excluidos los acogimientos "punitivos" adoptados como consecuencia de infracciones de Derecho penal cometidas por los menores ${ }^{15}$.

27. Una de las deficiencias en materia de responsabilidad parental del RB II bis, señalada por la Comisión en su Propuesta de Reglamento de 30 de junio de $2016^{16}$, se refiere, precisamente, al acogimiento del menor en otro Estado miembro. De acuerdo con el art. 56 RB II bis, un órgano jurisdiccional que considere el acogimiento del menor en otro Estado miembro está obligado, antes de ordenarlo, a consultar a la autoridad central de ese otro Estado para conocer si en el mismo se requiere la aprobación de una autoridad competente para los casos internos de acogimiento de menores. En caso afirmativo, la resolución de acogimiento solo podrá adoptarse en el Estado miembro requirente cuando la autoridad competente del Estado miembro requerido haya aprobado dicho acogimiento. Las autoridades centrales han señalado regularmente que a veces transcurren varios meses hasta que se comprueba si se requiere la aprobación en un caso concreto. Cuando es precisa la aprobación, el procedimiento para recabarla ha de seguir y es, al parecer, igual de lento, ya que no existe un plazo en el que las autoridades requeridas deban responder. Como consecuencia de ello, en la práctica, muchas autoridades requirentes ordenan el acogimiento y envían al niño al Estado receptor mientras el procedimiento de consulta sigue pendiente o incluso en el momento en el que empieza, al considerar la urgencia del acogimiento y ser conscientes de la lentitud de los procedimientos. Así, los Estados receptores se han quejado de que a menudo se acoge a los niños antes de que se haya dado la aprobación, lo que les deja en una situación de inseguridad jurídica.

28. Pues bien, el RB II ter pretende subsanar estos problemas simplificando el procedimiento y estableciendo un plazo máximo para que el Estado miembro requerido comunique la resolución por la que aprueba o deniega el acogimiento. Según el nuevo art. 82 RB II ter, el órgano jurisdiccional del Estado miembro requirente debe directamente dirigir a la autoridad central del Estado miembro requerido una solicitud de aprobación, salvo cuando el menor deba ser acogido por un progenitor, o por otros parientes cercanos si el Estado miembro requerido ha decidido que no es necesaria su aprobación para los acogimientos dentro de su propio territorio con determinadas categorías de parientes cercanos además de los progenitores (información que los Estados miembros han de comunicar a la Comisión y esta se encargará de publicar, en particular a través del Portal Europeo de e-Justicia). El Estado miembro requerido debe comunicar a la autoridad central requirente la resolución por la que se otorga o deniega la aprobación en el plazo máximo de tres meses desde la recepción de la solicitud, salvo que existan circunstancias excepcionales que lo impidan. El Estado miembro requirente solo podrá ordenar el acogimiento después de que la autoridad competente del Estado miembro requerido lo haya aprobado ${ }^{17}$.

\footnotetext{
${ }^{15}$ Cfr. Considerando 11 RB II ter.

16 Propuesta de Reglamento del Consejo relativo a la competencia, el reconocimiento y la ejecución de resoluciones en materia matrimonial y de responsabilidad parental, y sobre la sustracción internacional de menores (refundición) [Bruselas, 30.6.2016, COM(2016) 411 final, 2016/0190 (CNS)].

${ }^{17}$ En relación con el acogimiento de un menor en otro Estado miembro, el TJUE, en sentencia de 26 de abril de 2012, Health Service Executive, C-92/12 PPU, ha hecho declaraciones importantes, a efectos del art. 56 RB II bis, que son extrapolables al art. 82 RB II ter, a saber: $1^{\text {a }}$ ) la aprobación del acogimiento debe darla una autoridad competente de Derecho Público. No basta con que dé su aprobación el establecimiento en el que el menor ha de ser acogido; $2^{\mathrm{a}}$ ) la resolución judicial que ordena el acogimiento forzoso de un menor en régimen cerrado en un establecimiento en otro Estado miembro debe ser declarada ejecutiva en el Estado miembro requerido antes de ejecutarse en dicho Estado. La resolución del órgano jurisdiccional del Estado miembro requerido sobre la solicitud de declaración de ejecutoriedad debe dictarse con una particular celeridad, careciendo de efecto suspensivo los recursos interpuestos contra tal resolución, con el fin de no privar al Reglamento de su efecto útil; $3^{\text {a }}$ ) la aprobación dada
} 
El tiempo dirá si estas prevenciones contribuyen a solucionar los problemas actuales o si los Estados requeridos siguen retrasando la aprobación amparándose en circunstancias excepcionales.

e) Las medidas de protección del menor ligadas a la administración, conservación o disposición de sus bienes

29. En relación con los bienes del menor, el Reglamento se aplica únicamente a las medidas de protección del menor, es decir, a la designación y funciones de la persona o institución que vaya a ocuparse de los bienes del menor, de representarle o de prestarle asistencia, así como a las medidas de administración, conservación o disposición de sus bienes (p.ej. en caso de que exista un litigio entre los padres sobre la administración de los bienes del menor, o si el menor se queda huérfano). En cambio, las medidas relativas a los bienes del menor cuyo objetivo no sea la protección de este no conciernen a la responsabilidad parental y, por tanto, no están cubiertas por el Reglamento, sino que deben seguir rigiéndose por el Reglamento (UE) $n^{\circ} 1215 / 2012$, relativo a la competencia, el reconocimiento y la ejecución de resoluciones judiciales en materia civil y mercantil ${ }^{18}$. Es competencia de los órganos jurisdiccionales determinar en cada caso si una concreta medida relativa a los bienes del menor constituye o no una medida patrimonial protectora del menor, a los efectos de determinar el Reglamento aplicable.

30. Hay que señalar que el listado de materias de responsabilidad parental del art. 1.2 RB II ter no es exhaustivo, sino que esta norma tiene mero valor ejemplificativo o ilustrativo, como se deduce del empleo de la locución adverbial "en particular" que utiliza el art. 1.2 RB II ter, y como así viene sosteniendo el TJUE ${ }^{19}$.

31. La aplicación de las normas en materia de responsabilidad parental se produce con frecuencia en el marco de un proceso matrimonial, de ahí que resulte adecuado contar con un único instrumento jurídico europeo aplicable a las dos materias, la matrimonial y la de responsabilidad parental. Ahora bien, con la finalidad de asegurar la igualdad de todos los menores, estén sus padres casados o no lo estén, el RB II ter se aplica a todas las medidas y resoluciones en materia de responsabilidad parental, incluidas las medidas de protección del menor, con independencia de que estas medidas y resoluciones estén vinculadas o no a un procedimiento matrimonial ${ }^{20}$.

32. El RB II ter, a diferencia del RB II bis ${ }^{21}$, define el concepto de "menor" como toda persona que tenga menos de 18 años (art. 2.2.6), coincidiendo así con el ámbito de aplicación del otro instrumento legal internacional en materia de protección de los niños, el Convenio de La Haya de $1996^{22}$, que "se aplica a los niños a partir de su nacimiento y hasta que alcancen la edad de 18 años" (art. 2$)^{23}$.

por un periodo determinado no se aplicará a las resoluciones que tengan por objeto prorrogar la duración del acogimiento, sino que deberá solicitarse una nueva aprobación; y $4^{\mathrm{a}}$ ) una resolución de acogimiento adoptada en un Estado miembro y declarada ejecutiva en otro Estado miembro solo podrá ejecutarse en este último por el periodo indicado en la resolución de acogimiento.

${ }^{18}$ Cfr. Considerando 10 RB II ter.

${ }^{19}$ Cfr. STJUE de 27 de noviembre de 2007, C, C-435/06. En este mismo sentido, vid. STJUE de 26 de abril de 2012, Health Service Executive, C-92/12 PPU y STJUE de 21 de octubre de 2015, Gogova, C-215/15.

${ }^{20}$ Cfr. Considerandos 7 y 8 RB II ter. Téngase en cuenta que en las dos últimas décadas la tasa de hijos nacidos fuera del matrimonio ha aumentado considerablemente en todos los Estados miembros de la Unión Europea. Según los datos publicados por la Oficina estadística europea (Eurostat), existe una tendencia cada vez mayor en toda la Unión Europea de nacimientos fuera del matrimonio. En 2018, la tasa de mujeres europeas que tuvieron hijos sin estar casadas con su pareja llegaba ya al 43\%, lo que permite hablar claramente de "un cambio de patrones" en el modelo de familia europeo. Los números apuntan a que, en unos años, más de la mitad de los recién nacidos tendrán padres y madres no casados.

${ }^{21}$ El RB II bis no dice qué se entiende por "menor", por lo que hay que estar a la legislación nacional de cada Estado miembro.

${ }^{22}$ Convenio de 19 de octubre de 1996 Relativo a la Competencia, la Ley Aplicable, el Reconocimiento, la Ejecución y la Cooperación en materia de Responsabilidad Parental y de Medidas de Protección de los Niños.

${ }^{23}$ Un interesante análisis sobre las modificaciones que se introducen en el RB II ter para mejorar las relaciones con el Convenio de La Haya de 1996, puede verse en B. CAMPuZAno Díaz, "El nuevo Reglamento (UE) 2019/1111: análisis de las mejoras 
33. Hay que señalar, además, que el propio RB II ter, en su considerando 17, especifica que el Reglamento debe aplicarse a todos los menores de 18 años, aunque la persona antes de esa edad haya adquirido plena capacidad de obrar en virtud de su ley personal (por ejemplo, porque está emancipada por matrimonio $)^{24}$. Esto evita toda posible superposición o colisión con el ámbito de aplicación del Convenio de La Haya de 13 de enero de 2000 sobre Protección Internacional de los Adultos, que se aplica a partir de los 18, y al mismo tiempo, evita lagunas entre los dos instrumentos. En el caso de los menores hasta 16 años, debe seguir aplicándose el Convenio de La Haya de 1980 y, por tanto, también el Capítulo III del RB II ter sobre la sustracción internacional de menores, que complementa la aplicación del Convenio de La Haya de 1980 en las relaciones entre los Estados miembros, de conformidad con el art. 1.3 RB II ter.

34. En relación con las exclusiones materiales del Reglamento, el art. 1.4 RB II ter excluye expresamente de su ámbito de aplicación una serie de materias, algunas de ellas referidas a obligaciones de carácter asistencial o protector de los menores. Así, el RB II ter no se aplica a: a) las cuestiones relativas a la determinación y la impugnación de la filiación; b) las resoluciones sobre adopción y las medidas que la preparan, la anulación y revocación de la adopción; c) el nombre y apellidos del menor; d) la emancipación; e) las obligaciones de alimentos; f) los fideicomisos y las sucesiones, y g) las medidas adoptadas a consecuencia de infracciones del Derecho penal cometidas por los menores.

35. Según este listado, el presente Reglamento no debe aplicarse al establecimiento de la filiación, que es una cuestión distinta de la responsabilidad parental, ni tampoco a las demás cuestiones ligadas al estado de las personas, como la adopción, el nombre y apellidos y la emancipación ${ }^{25}$.

36. Quedan excluidas también las obligaciones de alimentos, a pesar de que, sin duda, se trata esta de una materia de responsabilidad parental, puesto que se refiere a la fijación de las obligaciones alimenticias que incumben a uno u otro progenitor respecto de sus hijos con el fin de garantizar que se cubren los gastos de la manutención y la educación de estos. El concepto de responsabilidad parental del RB II ter no incluye, pues, la contribución de los padres a los gastos de manutención y educación del hijo, contribución que está comprendida en el concepto de "obligación de alimentos" y entra dentro del ámbito de aplicación material del Reglamento $n^{\circ} 4 / 2009$, del Consejo, de 18 de diciembre de 2008, relativo a la competencia, la ley aplicable, el reconocimiento y la ejecución de resoluciones y la cooperación en materia de alimentos ${ }^{26}$. No obstante, los órganos jurisdiccionales competentes para conocer de una acción relativa a la responsabilidad parental tendrán generalmente competencia para conocer de las demandas relativas a las obligaciones de alimentos que sean accesorias de ella, salvo si esta competencia se basa únicamente en la nacionalidad de una de las partes (art. 3 d) Reglamento $n^{\circ}$ 4/2009). Según ha declarado el TJUE, "el juez competente para conocer de las acciones relativas a la responsabilidad parental es quien se halla en mejor situación para apreciar in concreto las consecuencias de una demanda relativa a la obligación de alimentos a favor de un hijo, y fijar el importe de dicha obligación, destinado a contribuir a los gastos de manutención y educación de los hijos, adaptándolo, según la modalidad de custodia establecida -compartida o exclusiva-, el derecho de visita, la duración de dicho derecho, y los

\footnotetext{
en las relaciones con el Convenio de La Haya de 19 de octubre de 1996 sobre responsabilidad parental", Cuadernos de Derecho Transnacional (Marzo 2020), Vol. 12, № 1, pp. 97-117.

${ }^{24}$ En este punto, el RB II ter se aparta del RB II bis, en el que no se hace ninguna referencia a los menores emancipados, y de la Guía práctica para la aplicación del Reglamento Bruselas II bis elaborada por la Comisión Europea en 2015, en la que expresamente se dice que las resoluciones dictadas respecto de los menores emancipados no se consideran en principio materia de responsabilidad parental y, por tanto, no entran en el ámbito de aplicación del Reglamento. A mi juicio, la aplicación del Reglamento a menores emancipados se compadece mejor con el principio del "interés superior del menor" que ha de informar cualquier interpretación y aplicación de las normas en esta materia, por lo que hay que celebrar la decisión del legislador europeo de incluirlos en el ámbito de aplicación del Reglamento En este sentido ya se ha manifestado P. OREJUDO PRIETO DE LOS Mozos, "Diez años de aplicación e interpretación del Reglamento Bruselas II bis sobre crisis matrimoniales y responsabilidad parental (análisis de los aspectos de competencia judicial internacional”, La ley. Unión Europea, núm. 21, 2014, p. 9.

${ }^{25}$ Vid. Considerando 12 RB II ter.

${ }^{26}$ Así lo ha declarado recientemente en TJUE en sentencia de 3 de octubre de 2019, OF y PG, C-759/18.
} 
demás elementos de carácter fáctico relativos al ejercicio de la responsabilidad parental de los que dicho juez tenga conocimiento" 27 .

37. Se excluyen los fideicomisos y las sucesiones. La sucesión por causa de muerte es objeto del Reglamento (UE) n ${ }^{\circ}$ 650/2012 del Parlamento Europeo y del Consejo de 4 de julio de 2012 relativo a la competencia, la ley aplicable, el reconocimiento y la ejecución de las resoluciones, a la aceptación y la ejecución de los documentos públicos en materia de sucesiones mortis causa y a la creación de un certificado sucesorio europeo.

38. Por último, se excluyen también las medidas adoptadas para sancionar la comisión de una infracción penal por el menor (por ejemplo, queda excluido el internamiento de un menor que implique privación de libertad cuando dicha medida se ordene no para proteger al menor sino para sancionarlo por la comisión de un acto que, de haber sido cometido por un adulto, sería constitutivo de delito con arreglo al Derecho penal nacional).

\section{La materia de responsabilidad parental a la luz de la jurisprudencia del TJUE}

39. Durante los más de quince años de vigencia del RB II bis, son muchas las cuestiones prejudiciales que se han planteado ante el Tribunal de Justicia de la Unión Europea sobre cómo ha de interpretarse el concepto de "responsabilidad parental" a efectos del Reglamento. Estas peticiones de decisión prejudicial han servido para formar un cuerpo de doctrina jurisprudencial al respecto que conviene repasar. Obviamente, las resoluciones del TJUE que se exponen a continuación -por orden cronológicose refieren siempre al RB II bis, pero su doctrina resulta íntegramente aplicable al nuevo RB II ter. Es más, algunas de las declaraciones realizadas por el Tribunal de Justicia en estas resoluciones han sido incorporadas por el legislador europeo en el nuevo Reglamento.

\section{Decisión relativa a la guarda de menores y a su acogimiento fuera del domicilio familiar}

40. La STJUE de 27 de noviembre de 2007, C, C-435/06, estableció que la decisión de asumir la guarda de un menor con la finalidad de entregarlo en acogimiento, aunque no figure expresamente entre las materias enumeradas en el art. 1.2 del Reglamento, constituye una resolución relativa a la responsabilidad parental y, por consiguiente, debe entenderse incluida en su ámbito de aplicación.

41. La cuestión prejudicial que resuelve esta sentencia la planteó el Tribunal Administrativo Supremo finlandés en el marco de un recurso presentado por la madre de los menores contra la resolución del Tribunal Administrativo de Oulu, Finlandia, por la que se confirmaba la orden de la policía finlandesa de entregar a los menores a las autoridades suecas, en cumplimiento de una resolución judicial sueca por la que, en unidad de acto, se asumía la guarda inmediata de los menores con la finalidad de entregarlos en acogimiento a una familia de acogida. El Tribunal finlandés remitente deseaba saber si

${ }^{27}$ STJUE de 16 de julio de 2015, A y B, C-184/14. En esta sentencia el TJUE declaró que "cuando un órgano jurisdiccional de un Estado miembro conoce de una acción de separación o de ruptura del vínculo conyugal entre los padres de un hijo menor de edad y un órgano jurisdiccional de otro Estado miembro conoce de una acción de responsabilidad parental en relación con ese menor, una demanda relativa a una obligación de alimentos a favor de ese hijo sólo es accesoria a la acción relativa a la responsabilidad parental en el sentido del artículo 3, letra d), de dicho Reglamento". Esta declaración ha sido posteriormente matizada por el TJUE en el sentido de que "en caso de que ante un órgano jurisdiccional de un Estado miembro se interponga un recurso que comprende tres pretensiones relativas, respectivamente, al divorcio de los progenitores de un menor, a la responsabilidad parental respecto de ese menor y a la obligación de alimentos hacia este, el órgano jurisdiccional que resuelve sobre el divorcio y que se ha declarado incompetente para pronunciarse sobre la pretensión relativa a la responsabilidad parental es competente, sin embargo, para resolver sobre la pretensión relativa a la obligación de alimentos respecto a dicho menor, cuando es también el órgano jurisdiccional de la residencia habitual del demandado o el órgano jurisdiccional ante el que este ha comparecido, sin impugnar su competencia" (STJUE de 5 de septiembre de 2019, $R$ y $P$, C-468/18). 
el Reglamento se refiere a la vez a la guarda y al acogimiento de menores o únicamente a la resolución sobre acogimiento, habida cuenta de que en Finlandia la protección de menores requiere la adopción, no de una, sino de varias resoluciones.

42. Las razones esgrimidas por el Tribunal de Luxemburgo para entender comprendida dentro del concepto de responsabilidad parental una resolución por la que, en unidad de acto, se decide asumir la guarda inmediata de un menor y ordenar su acogimiento en una familia de acogida son las siguientes: i) el Reglamento - de conformidad con su considerando quinto ${ }^{28}$ se aplica a todas las resoluciones en materia de responsabilidad parental, incluidas las medidas de protección del menor, y la decisión sobre la guarda de un menor "se inscribe, por naturaleza, dentro del marco de una acción pública cuya finalidad es satisfacer las necesidades de protección y asistencia de los menores; ii) en Finlandia, la asunción de la guarda de un menor tiene el efecto de conferir a los servicios sociales de dicho Estado el poder para determinar el lugar de residencia del menor. Dicha medida puede afectar al ejercicio del derecho de custodia que, según dispone el propio Reglamento, comprende el derecho a decidir sobre el lugar de residencia del menor. Por tanto, dicha facultad afecta a la responsabilidad parental, puesto que el derecho de custodia constituye una de las materias relativas a dicha responsabilidad; y iii) la guarda de un menor se encuentra estrechamente vinculada al acogimiento, que forma parte expresamente del elenco de materias relativas a la responsabilidad parental, "en el sentido de que, por una parte, una decisión aislada de asumir la guarda únicamente puede ser adoptada como medida provisional y, por otra parte, el acogimiento de un menor en contra de la voluntad de los padres, únicamente puede llevarse a cabo si la autoridad asume antes la guarda de ese menor. En tales circunstancias, excluir del ámbito de aplicación del Reglamento (...) la decisión de asumir la guarda de un menor comprometería la eficacia de dicho Reglamento en los Estados en los que la protección de los menores, incluido su acogimiento, requiere la adopción de varias decisiones".

\section{Medidas de protección de menores regidas por el Derecho público}

43. En la cuestión prejudicial anterior, asunto $C$, el órgano jurisdiccional remitente planteó también al Tribunal de Justicia la concreta cuestión de si el Reglamento resulta aplicable a las decisiones de asumir la guarda y ordenar el acogimiento de un menor que se rigen por el Derecho público, habida cuenta de que el ámbito de aplicación del Reglamento se circunscribe a las "materias civiles", según dispone el art. 1.1.

44. El TJUE recuerda primero que, de conformidad con la jurisprudencia ya consolidada del Tribunal de Justicia, el concepto de "materias civiles" que emplea el Reglamento debe ser objeto de una interpretación autónoma en Derecho comunitario que debe hacerse a la luz, en primer lugar, de los objetivos que persigue el Reglamento -entre los que figura la igualdad de trato de todos los menores- $y$, en segundo lugar, de los principios generales que se deducen de todos los sistemas jurídicos nacionales ${ }^{29}$. $\mathrm{Y}$, a continuación, manifiesta contundentemente que "ni la organización jurisdiccional de los Estados miembros ni la atribución de competencia a las autoridades administrativas pueden influir en el ámbito de aplicación de este Reglamento ni en la interpretación del concepto de "materias civiles" (...), que debe interpretarse en el sentido de que incluso puede englobar medidas que, desde el punto de vista del ordenamiento jurídico de un Estado miembro, están sometidas al Derecho Público". De lo contrario, esto es, "si las decisiones de asumir la guarda y de ordenar el acogimiento de un menor que, en determinados Estados miembros, se rijan por el Derecho Público debieran, por este mero motivo, quedar excluidas del ámbito de aplicación de dicho Reglamento, se comprometería manifiestamente el propio objetivo de reconocimiento mutuo y de ejecución de las resoluciones en materia de responsabilidad parental"30.

\footnotetext{
${ }^{28}$ En el mismo sentido se expresa ahora el considerando 7 RB II ter.

${ }^{29}$ Por todas, vid. STJUE de 14 de noviembre de 2002, Baten, C-271/00 y STJUE de 28 de abril de 2009, Meletis Apostolides, C-420/07.

${ }^{30}$ Tan solo un año después de planteada la cuestión prejudicial en el asunto $C$, el mismo órgano jurisdiccional remitente, el
} 
45. Esta interpretación jurisprudencial ha sido acogida expresamente en el RB II ter. Así, en su considerando 4, puede leerse lo siguiente: “(...) Por consiguiente, el concepto de materia civil debe interpretarse en el sentido de que también puede abarcar medidas que, desde el punto de vista del sistema jurídico de un Estado miembro, pueden estar sometidas al Derecho público. Debe abarcar en particular todas las demandas, medidas o resoluciones en materia de responsabilidad parental en el sentido del presente Reglamento, de conformidad con sus objetivos».

\section{Acogimiento en régimen cerrado en un establecimiento}

46. En materia de acogimiento, la STJUE de 26 de abril de 2012, Health Service Executive, C-92/12 PPU, declaró que el concepto de "acogimiento de un menor en un establecimiento" del art. 1.2.d) del Reglamento debe interpretarse en el sentido de que incluye el acogimiento en régimen cerrado en un establecimiento, siempre que dicho acogimiento se ordene para proteger al menor y no para sancionarlo, es decir, siempre que la privación de libertad del menor sea con fines terapéuticos y educativos. Por el contrario, las medidas de internamiento de un menor que sancionen la comisión de una infracción penal quedan excluidas del ámbito de aplicación del Reglamento ex art. 1.4 g).

47. Efectivamente, cualquier otra interpretación impediría beneficiarse del Reglamento a los menores particularmente vulnerables que necesitan tal acogimiento y sería contraria a la finalidad del Reglamento, que es la de garantizar la igualdad de todos los menores.

48. La doctrina de esta sentencia ha sido recogida por el RB II ter en su considerando 11, en cuya virtud deben incluirse en el ámbito de aplicación del Reglamento "los "acogimientos educativos" ordenados por un órgano jurisdiccional o concertados por una autoridad competente con el acuerdo de los progenitores del menor. Únicamente deben quedar excluidos los casos en que el acogimiento, ya sea educativo o punitivo, haya sido ordenado o concertado como consecuencia de un acto del menor que, de haber sido cometido por un adulto, podría ser constitutivo de delito con arreglo al Derecho penal nacional, con independencia de si en este caso concreto puede conducir a una condena".

\section{Aprobación de un acuerdo de reparto sucesorio concluido por el tutor}

49. En la sentencia de 6 de octubre de 2015, Matoušková, C-404/14, el TJUE resuelve una cuestión prejudicial planteada por el Tribunal Supremo (República Checa), acerca de si la aprobación por el juez de tutelas de un acuerdo de reparto sucesorio concluido entre el cónyuge supérstite y los hijos menores representados por un tutor constituye una medida relativa al ejercicio de la responsabilidad parental, estando, por tanto, incluida en el ámbito de aplicación del Reglamento o si, por el contrario, constituye una medida relativa a las sucesiones, excluidas expresamente de su ámbito de aplicación.

50. Para el Tribunal de Justicia, la aprobación del acuerdo de reparto sucesorio concluido por el tutor de menores por cuenta de estos -aun cuando haya sido solicitada en un procedimiento sucesorioes una medida adoptada teniendo en cuenta la capacidad jurídica del menor, que constituye una medida de protección y de asistencia del menor relacionada con la administración, la conservación o la disposición de sus bienes en el marco del ejercicio de la autoridad parental y, por consiguiente, debe entenderse incluida en el ámbito de aplicación del Reglamento.

Tribunal Administrativo Supremo de Finlandia, volvió a plantear la misma cuestión prejudicial redactada exactamente en los mismos términos. La respuesta del TJUE fue exactamente la misma (STJUE de 2 de abril de 2009, A, C-523/07). 


\section{Viaje de un menor fuera del Estado en que reside y expedición de un pasaporte a su nombre}

51. En la STJUE de 21 de octubre de 2015, Gogova, C-215/15, el Tribunal de Justicia declaró que la acción por la que uno de los progenitores solicita al juez que supla la falta de consentimiento del otro progenitor al viaje de su hijo menor de edad fuera del Estado miembro en que este reside y a la expedición de un pasaporte a su nombre tiene por objeto el ejercicio de la responsabilidad parental sobre el menor y, por tanto, está incluida en el ámbito de aplicación del Reglamento. Esto es así incluso en el caso de que la resolución que se dicte al término del proceso judicial deba ser tenida en cuenta por las autoridades del Estado miembro del que el menor es nacional en el procedimiento administrativo de expedición de un pasaporte a nombre de dicho menor.

52. No desvirtúa esta conclusión el mero hecho de que la demanda tenga por objeto una resolución judicial concreta relativa a un menor, y no el conjunto de modalidades de ejercicio de la responsabilidad parental. El Reglamento se aplica a todas las resoluciones en materia de responsabilidad parental, tanto si se refieren a un aspecto concreto de dicha responsabilidad como si regulan el ejercicio de la misma con carácter general.

\section{Autorización para repudiar la herencia del abuelo presentada por los progenitores del menor}

53. Con los mismos argumentos que en el asunto Matoušková, la STJUE de 19 de abril de 2018, Alessandro Saponaro C-565/16, declaró que una solicitud de autorización destinada a repudiar una herencia presentada por los progenitores de un menor en nombre de este guarda relación con el estado y la capacidad de la persona y, por tanto, está comprendida en el ámbito de la responsabilidad parental, y no del Derecho de sucesiones y, por ende, forma parte del ámbito de aplicación del Reglamento.

\section{Derecho de visita de los abuelos}

54. La Sala Primera del TJUE, en sentencia de 31 de mayo de 2018, Valcheva, C-335/17, se ha pronunciado sobre el concepto de "derecho de visita" que el Reglamento incluye de forma expresa en la materia de responsabilidad parental y, en concreto, sobre si este derecho comprende o no el derecho de visita de los abuelos a los nietos.

55. La petición de decisión prejudicial fue presentada por el Tribunal Supremo de Casación (Bulgaria), en el marco de un litigio entre la Sra. Neli Valcheva, residente en Bulgaria, y su ex yerno, residente en Grecia, en relación con el derecho de visita de la abuela a su nieto, menor edad y residente en Grecia bajo la custodia de su padre. La abuela solicitó a un órgano jurisdiccional de primera instancia búlgaro que estableciera el régimen de ejercicio del derecho de visita entre ella y su nieto. El órgano de primera instancia entendió que carecía de competencia internacional para examinar la pretensión por aplicación del RB II bis que, en materia de responsabilidad parental, atribuye la competencia a los tribunales del Estado miembro donde el menor tiene su residencia habitual, es decir, a los tribunales griegos; decisión que fue confirmada por el tribunal de apelación. Interpuesto recurso de casación por la abuela, el Tribunal Supremo búlgaro decidió suspender el procedimiento y plantear al TJUE la cuestión prejudicial acerca de cómo ha de interpretarse el concepto de "derecho de visita" del Reglamento, en el sentido de si se aplica solo a la visita de los progenitores al menor o también a la visita de otros miembros de la familia y, en particular, de los abuelos y abuelas, habida cuenta de que el Reglamento al definir el derecho de visita no lo precisa.

56. El Tribunal de la Unión, teniendo en cuenta que el RB II bis, a diferencia de su predecesor, el Reglamento $n^{\circ} 1347 / 2000$, no está limitado a los litigios en que sean partes los progenitores, sino que toma en consideración todas las resoluciones judiciales relativas a la responsabilidad parental y, por con- 
siguiente, al derecho de visita, con independencia de la calidad de las personas que pudieran ejercerlo y sin excluir a los abuelos, ha declarado que el concepto de "derecho de visita" del Reglamento incluye no solo el derecho de visita de los progenitores a sus hijos, sino también el de otras personas con las que resulte importante que el menor mantenga relaciones personales, en particular, sus abuelos, sean o no titulares de la responsabilidad parental.

57. Si el derecho de visita no alcanzara a estas otras personas -señala el TJUE-, no solo podrían dirimir las cuestiones relativas a este derecho el órgano jurisdiccional al que el RB II bis atribuya la competencia, sino también otros órganos jurisdiccionales que pudieran considerarse competentes con arreglo al Derecho internacional privado, con el riesgo evidente de resoluciones contradictorias o incompatibles, pudiendo darse el caso de que el derecho de visita concedido a un allegado del menor fuera contrario al atribuido a un beneficiario de la responsabilidad parental. Comoquiera que la atribución de un derecho de visita a una persona distinta de los progenitores puede interferir en los derechos y deberes de estos, procede, para evitar medidas contradictorias y en interés superior del menor, que sea el mismo órgano jurisdiccional, es decir, el de la residencia habitual del menor, el que se pronuncie sobre los derechos de visita.

58. Sentada esta doctrina por el TJUE, habría resultado adecuado que el legislador europeo hubiese incluido expresamente en el RB II ter el derecho de los menores a tener contacto no solo con sus progenitores, sino también con aquellas personas con quienes tengan lazos familiares, como sus abuelos, en el concepto de "derecho de visita" definido en el art. 2.2.10) del nuevo Reglamento o, al menos, como ha hecho con otras declaraciones del TJUE, en alguno de sus considerandos, pero, lamentablemente, no ha sido así.

\section{La competencia judicial internacional en materia de responsabilidad parental en el RB II ter}

\section{La residencia habitual del menor en un Estado miembro como criterio de aplicación del RB II ter}

59. En materia de responsabilidad parental, la aplicación del RB II ter está sujeta a que el menor tenga su residencia habitual en un Estado miembro de la Unión Europea. Si el menor tiene su residencia habitual en un Estado miembro, la aplicación del Reglamento resulta indiscutible y, por consiguiente, los órganos jurisdiccionales de cualquier Estado miembro tendrán que determinar su competencia judicial internacional exclusivamente con arreglo a los foros recogidos en el Reglamento. En este caso, las normas de competencia del Convenio de La Haya de 1996 resultan inaplicables, tal y como establece el art. 97 RB II ter que regula la relación del RB II ter con el Convenio.

60. Por el contrario, si el menor no tiene su residencia habitual en un Estado miembro, bien porque la tenga en un tercer Estado o bien porque no la tenga en ningún país concreto, el RB II ter no resulta, en principio, aplicable -al menos, no en su integridad- y, por tanto, la competencia judicial internacional en cada Estado miembro de la Unión Europea se determinará con arreglo a las normas del Convenio de La Haya de 1996.

61. No obstante, no es esta una cuestión pacífica. Ciertamente, en materia de responsabilidad parental, la aplicación del conjunto de normas de competencia del RB II ter depende de que el menor tenga su residencia habitual en alguno de los Estados miembros de la UE. Sin embargo, cabe plantearse la posibilidad, como veremos después, de que una de sus normas, el art. 10, relativa a la "elección del órgano jurisdiccional", resulte aplicable aun cuando el menor tenga su residencia habitual en un Estado no comprendido en el ámbito espacial del Reglamento. La cuestión que se plantea en relación con esta norma de competencia, que permite -bajo ciertas condiciones estrictas- a los padres del menor someterse expresamente a los órganos jurisdiccionales de un Estado miembro que no es en el que reside habitualmente el menor, es la de si opera solo cuando el menor reside en un (otro) Estado miembro, o 
lo hace "con independencia de la residencia habitual del menor", es decir, también cuando este reside habitualmente en un tercer Estado ${ }^{31}$.

\section{El interés superior del menor}

62. Las normas de competencia en materia de responsabilidad parental están concebidas en función del "interés superior del menor", y deben aplicarse de acuerdo con este. Cualquier referencia al interés superior del menor debe interpretarse a la luz del art. 24 de la Carta de los Derechos Fundamentales de la Unión Europea ${ }^{32}$ y de la Convención de las Naciones Unidas sobre los Derechos de Niño, aprobada como tratado internacional de derechos humanos el 20 de noviembre de 1989, tal y como son aplicadas por las legislaciones y procedimientos nacionales ${ }^{33}$.

63. Tanto el art. 24.2 CDFUE como el art. 3.1 de la Convención sobre los Derechos del Niño exigen que en todas las decisiones y medidas concernientes a los niños se atienda siempre al interés superior del menor como "consideración primordial", lo que significa que el interés superior del menor no puede estar al mismo nivel que todas las demás consideraciones.

64. Sobre el derecho del menor a que su interés superior sea una consideración primordial, resulta altamente recomendable la lectura de la Observación General no 14 (2013) del Comité de los Derechos del Niño de las Naciones Unidas (CRC/GC/2013/14). Mediante esta Observación, el Comité, órgano designado por las Naciones Unidas para interpretar el sentido de los artículos que contiene la Convención de los Derechos del Niño, marca las pautas para entender en profundidad este derecho.

65. El Comité ha determinado que, junto con el derecho a la no discriminación, el derecho a la vida y el desarrollo, y el derecho del niño a ser escuchado, la consideración primordial del interés superior del menor constituye uno de los cuatro principios generales de la Convención, lo que pone de relieve que no solo se trata de un derecho en sí mismo, sino que también debe tenerse en cuenta para interpretar y hacer respetar todos los demás derechos del niño.

66. En esta Observación, el Comité subraya que el interés superior del niño es un concepto triple, a saber: un derecho sustantivo, un principio jurídico interpretativo y una norma de procedimiento.

67. "a) Un derecho sustantivo: el derecho del niño a que su interés superior sea una consideración primordial que se evalúe y tenga en cuenta al sopesar distintos intereses para tomar una decisión sobre una cuestión debatida, y la garantía de que ese derecho se pondrá en práctica siempre que se tenga que adoptar una decisión que afecte a un niño, a un grupo de niños concreto o genérico o a los niños en general. El artículo 3, párrafo 1, establece una obligación intrínseca para los Estados, es de aplicación directa (aplicabilidad inmediata) y puede invocarse ante los tribunales.

68. b) Un principio jurídico interpretativo fundamental: si una disposición jurídica admite más de una interpretación, se elegirá la interpretación que satisfaga de manera más efectiva el interés superior del niño. Los derechos consagrados en la Convención y sus Protocolos facultativos establecen el marco interpretativo.

69. c) Una norma de procedimiento: siempre que se tenga que tomar una decisión que afecte a un niño en concreto, a un grupo de niños concreto o a los niños en general, el proceso de adopción

\footnotetext{
31 Vid. infra, V. 3. C) c).

${ }^{32}$ Considerando 19 RB II ter.

33 Vid., J.J. VARa PARRa, "El interés del menor en los foros de competencia judicial para las acciones de responsabilidad parental en el Reglamento (CE) Núm. 2201/2003”, R. E.D. L, vol. LVIII (2006).
} 
de decisiones deberá incluir una estimación de las posibles repercusiones (positivas o negativas) de la decisión en el niño o los niños interesados. La evaluación y determinación del interés superior del niño requieren garantías procesales. Además, la justificación de las decisiones debe dejar patente que se ha tenido en cuenta explícitamente ese derecho. En este sentido, los Estados partes deberán explicar cómo se ha respetado este derecho en la decisión, es decir, qué se ha considerado que atendía al interés superior del niño, en qué criterios se ha basado la decisión y cómo se han ponderado los intereses del niño frente a otras consideraciones, ya se trate de cuestiones normativas generales o de casos concretos".

\section{El sistema de fueros del RB II ter}

70. Antes de empezar a examinar las normas de competencia judicial en materia de responsabilidad parental del RB II ter, hay que señalar que se trata de normas de competencia internacional, es decir, normas que atribuyen competencia judicial internacional a los órganos jurisdiccionales de un Estado miembro de la Unión Europea, sin afectar a la competencia territorial, de modo que la ulterior fijación del órgano jurisdiccional territorialmente competente se determina, no por la norma europea, sino por la lex fori del tribunal del Estado miembro al que apunta el Reglamento. Es cierto que en los últimos años es tendencia que las normas europeas contengan algunos foros mixtos de competencia internacional y de competencia territorial, es decir, normas que determinan no solo los órganos jurisdiccionales de qué Estado miembro son los competentes, sino también, los órganos jurisdiccionales de qué lugar, dentro del territorio de ese Estado, lo son ${ }^{34}$. Pero hay que hacer notar que en estos casos el legislador europeo siempre utiliza la misma fórmula y se refiere a los órganos jurisdiccionales "del lugar del Estado miembro (...)", y no a los órganos jurisdiccionales "del Estado Miembro (...)". Así, por ejemplo, el Reglamento (UE) $n^{\circ} 1215 / 2012$ (materia civil y mercantil), contiene foros legales -la mayoría- que son solo de competencia internacional y algunos otros que son de competencia internacional y de competencia territorial (p. ej. casi todos los foros especiales por razón de la materia del art. 7) ${ }^{35}$. Pues bien, en ninguna de las normas de competencia en materia de responsabilidad parental del RB II ter se hace referencia a los órganos jurisdiccionales del lugar del Estado miembro, sino sencillamente a los órganos jurisdiccionales del Estado miembro, como regla, del Estado miembro de residencia habitual del menor en el momento en que se acuda al órgano jurisdiccional ${ }^{36}$.

${ }^{34}$ Para algunos autores, esta regulación resulta eficiente y evita que los litigantes tengan que informarse sobre las normas de Derecho Procesal interno de cada Estado miembro para poder determinar los concretos tribunales que son competentes para decidir el litigio internacional (cfr. A. L. Calvo Caravaca / J. Carrascosa González, con cita de M. Desantes Real / J.L. Iglesias Buhigues, Derecho Internacional Privado, Vol. I, Comares, Granada, 2016, p.127.

${ }^{35}$ Vid., también, p. ej. el art. 3 Reglamento (CE) no 4/2009 (obligaciones de alimentos), que atribuye la competencia al órgano jurisdiccional "del lugar donde el demandado tenga su residencia habitual" o "del lugar donde el acreedor tenga su residencia habitual".

${ }^{36}$ Recientemente, el pasado 22 de enero de 2020, el Juzgado de lo Mercantil $\mathrm{n}^{\circ} 2$ de Madrid le ha planteado al TJUE una cuestión prejudicial -pendiente de resolución- sobre la interpretación que ha de hacerse del art. 7.2 del Reglamento (UE) $n^{\circ}$ 1215/2012 que, en materia delictual o cuasidelictual atribuye la competencia al órgano jurisdiccional "del lugar donde se haya producido o pueda producirse el hecho dañoso". La pregunta del Juzgado español es la siguiente: "idebe interpretarse en el sentido de que solo establece la competencia internacional de los órganos jurisdiccionales del Estado miembro donde se encuentre dicho lugar, de forma que para la concreción del juez nacional territorialmente competente dentro de ese Estado se hace una remisión a las normas procesales internas, o debe interpretarse como una norma mixta que, por tanto, determina directamente tanto la competencia internacional como la competencia territorial nacional, sin necesidad de efectuar remisiones a la normativa interna? Espero que con la respuesta del TJUE se ponga solución a esta cuestión en el sentido que hemos apuntado, es decir que, en este caso concreto, se trata de una norma de competencia mixta, habida cuenta de que la competencia no se atribuye a los órganos jurisdiccionales del Estado miembro en el que se produjo o pueda producirse el daño, sino a los órganos jurisdiccionales del lugar donde se haya producido o pueda producirse el hecho dañoso. Y espero, también, que la resolución del TJUE, si se pronuncia en el sentido apuntado, sirva al legislador europeo para cuidar más el lenguaje a la hora de redactar las normas, pues en ocasiones se utilizan estas dos expresiones sin una intención deliberada de marcar la diferencia entre la competencia internacional y la territorial. Así, por ejemplo, sin salirnos del RB II ter, aunque ninguna de sus normas de competencia habla de "el lugar de residencia habitual del menor", sino "del Estado miembro de residencia habitual del menor", sí encontramos la referencia al lugar de residencia habitual del menor en algunos de sus considerandos (18 y 22, p. ej.). 
71. El RB II ter regula la normas de competencia judicial internaciona ${ }^{37}$ relativas a los litigios sobre responsabilidad parental en la Sección 2 del Capítulo II. La distribución de la competencia judicial se realiza a través de un sistema complejo de diversos tipos de foros o fueros, es decir, criterios jurídicos que atribuyen competencia internacional a los órganos jurisdiccionales de un Estado miembro ${ }^{38}$. Los fueros utilizados por el RB II ter son los siguientes: a) fuero de la residencia habitual del menor en el momento en que se acude al órgano jurisdiccional (art.7); b) fuero de la anterior residencia habitual del menor en casos de cambio legal de residencia del menor de un Estado miembro a otro (art. 8), y de traslado o retención ilícitos de un menor (art. 9); c) elección de fuero (art. 10); y d) fuero de la presencia del menor (art. 11). Junto a ellos, el Reglamento contiene dos normas (arts. 12 y 13) que permiten al tribunal competente remitir el asunto a un tribunal de otro Estado miembro mejor situado para valorar el interés superior del menor (forum non conveniens), una norma de competencia residual (art. 14), otra que atribuye competencia para adoptar medidas provisionales o cautelares a tribunales de un Estado miembro no competente para conocer del fondo del asunto (art. 15) y, por último, el art. 16 cierra esta Sección 2 con una norma de competencia para conocer de cuestiones incidentales ${ }^{39}$.

72. Es común, antes de pasar a exponer los fueros de competencia internacional de cualquier Reglamento, clasificarlos y establecer un orden de jerarquía o prelación entre ellos en orden a su aplicación, y exponerlos siguiendo ese orden. En este caso, empero, considero preferible examinar los fueros en el orden en que están recogidos en el Reglamento y fijar después las relaciones que existen entre ellos. Comencemos, pues, por el fuero general, alrededor del cual se articula todo el sistema de fueros del Reglamento.

\section{A) El fuero general: la residencia habitual del menor}

73. El art. 7 RB II ter establece el fuero general, aplicable en todos los casos, aunque con algunas excepciones. Este fuero general, que sigue el criterio de proximidad para salvaguardar el interés superior del menor ${ }^{40}$, es el de la "residencia habitual" del menor en el momento en que se acuda al órgano jurisdiccional. Así lo expresa el aptdo.1 del art. 7: "los órganos jurisdiccionales de un Estado miembro serán competentes en materia de responsabilidad parental respecto de un menor que resida habitualmente en dicho Estado miembro en el momento en que se acuda al órgano jurisdiccional" ${ }^{41}$.

74. El legislador europeo ha estimado, pues, que el órgano jurisdiccional geográficamente próximo a la residencia habitual del menor en el momento en que se acude al órgano jurisdiccional es el mejor situado para apreciar las medidas que han de adoptarse en su interés ${ }^{42}$. En esta elección se mezclan consideraciones de dos tipos: por un lado, la cercanía del tribunal a la fuente de prueba (el menor), lo que facilita las cosas a la hora de, en su caso, practicar prueba sobre el menor y escuchar

\footnotetext{
${ }^{37}$ Empleo las denominaciones generalmente aceptadas de "competencia internacional" o "competencia judicial internacional", aunque parte de la doctrina considera que las normas que determinan en qué casos deben conocer los órganos jurisdiccionales de un Estado son, propiamente, normas de jurisdicción, quedando reservado el término competencia para aquellas que designan un órgano jurisdiccional concreto. Sobre el concepto y caracteres de la competencia judicial internacional, vid., A. L. Calvo Caravaca / J. Carrascosa González, Derecho Internacional Privado, Vol. I, cit., p. 131-140.

${ }^{38}$ Sobre el concepto, el fundamento y la clasificación de los foros de competencia judicial internacional, vid., nuevamente, A. L. Calvo Caravaca / J. Carrascosa González, Derecho Internacional Privado, Vol. I, cit., p. 160-165.

${ }^{39}$ El sistema de fueros del RB II bis puede verse en B. Vidal Fernández, "Sistema de atribución de competencia", en A. de la Oliva Santos / F. Gascón Inchausti (dirs.), Competencia judicial internacional, reconocimiento y ejecución de resoluciones judiciales en la Unión Europea, Aranzadi, Cizur Menor (Navarra), 2011, pp. 475-486. Vid., también, R. CARo GÁNDARA, “Ámbito de aplicación y reglas de competencia del Reglamento 2201/2003 en materia de responsabilidad parental”, en $A E D P r$, t. V, 2005, pp.391-412.

${ }^{40} \mathrm{Cfr}$. Considerando $20 \mathrm{RB}$ II ter.

${ }^{41}$ El RB II ter mantiene el fuero general de competencia del RB II bis: el art. 7 RB II ter se corresponde con el art. 8 del RB II bis, según la tabla de correspondencias que figura en el Anexo X del nuevo Reglamento.

42 Vid., STJUE de 15 de junio de 2010, Purruker y Vallés Pérez, C-256/09, apartado 91.
} 
sus opiniones ${ }^{43}$; y, por otro lado, de protección del interés superior del menor, en términos de evitar que tenga que desplazarse fuera de su país, relacionarse con personas que probablemente no hablen su idioma materno, etc.

75. La residencia habitual del menor no constituye un punto de conexión innovador del RB II ter en materia de responsabilidad parental. Su predecesor, el RB II bis, actualmente en vigor, ya emplea este concepto como criterio general de competencia judicial internacional en esta materia. De hecho, en los últimos años, los instrumentos jurídicos internacionales y, en especial, los relativos al Derecho de familia, utilizan cada vez más el concepto de "residencia habitual" como punto de conexión suficiente para atribuir a los tribunales de un Estado la competencia judicial internacional ${ }^{44}$.

76. Pese a su innegable importancia para el correcto funcionamiento del sistema de competencia jurisdiccional establecido, el RB II ter, al igual que su predecesor, no contiene ninguna definición del concepto de "residencia habitual" del menor. Del uso del adjetivo habitual podría inferirse la exigencia de cierta duración, estabilidad o regularidad de la residencia para que esta pueda calificarse como tal, sin embargo, no ha de descartarse la posibilidad de que un menor, que cambie legalmente de residencia de un Estado miembro a otro, adquiera su residencia habitual en el nuevo Estado miembro el mismo día de su llegada, o poco después. Corresponderá al órgano jurisdiccional determinar en cada caso si un menor tiene o no su residencia habitual en un Estado miembro basándose en los hechos aplicables a la situación concreta de ese menor.

77. Según jurisprudencia reiterada, se desprende de las exigencias tanto de la aplicación uniforme del Derecho de la Unión como del principio de igualdad, que el tenor de una disposición de Derecho de la Unión que no contenga una remisión expresa al Derecho de los Estados miembros para determinar su sentido y alcance, debe ser objeto normalmente en toda la Unión Europea de una interpretación autónoma y uniforme que debe buscarse teniendo en cuenta el contexto de dicha disposición y el objetivo que la normativa de que se trate pretende alcanzar. Así pues, comoquiera que los preceptos del RB II ter en los que se emplea el concepto de residencia habitual no contienen ninguna remisión expresa al Derecho de los Estados miembros, procede definir este concepto con arreglo a los objetivos y fines del Reglamento. No cabe, por tanto, que un tribunal de un Estado miembro acuda a su Derecho nacional para dotar de contenido a este concepto.

78. Este fuero general solo otorga competencia judicial internacional a los órganos jurisdiccionales de un "Estado miembro". Si en el momento en que se acude a los tribunales el menor tiene su residencia habitual en un Estado no miembro de la Unión Europea, el fuero general del art. 7.1 RB II ter no resulta operativo, y no otorga competencia judicial internacional a ningún tribunal de ningún otro país.

79. La competencia ha de verificarse y determinarse, en cada caso particular, en el momento en que se promueva un procedimiento ante un órgano jurisdiccional. Es, por tanto, el lugar de residencia habitual que tuviere el menor en el momento en que se presenta el escrito de demanda o documento equivalente ante un órgano jurisdiccional el que ha de tenerse en cuenta para determinar la competencia judicial internacional del tribunal ${ }^{45}$. Y la competencia no persiste una vez concluido el procedimiento.

${ }^{43}$ El art. 21 RB II ter recoge expresamente el derecho del menor a expresar sus opiniones y el deber de los órganos jurisdiccionales de tenerlas en cuenta, de acuerdo con la edad y madurez del menor, a la hora de valorar el interés superior del menor (vid. Considerando 39 RB II ter).

${ }^{44}$ Entre los instrumentos internacionales, vid., entre otros, el Convenio de La Haya de 1996, y entre los europeos, vid., p. ej. el Reglamento (UE) $n^{\circ}$ 650/2012, en materia de sucesiones mortis causa, el Reglamento (UE) 2016/1103, en materia de regímenes matrimoniales y el Reglamento (UE) 2016/1104, en materia de efectos patrimoniales de las uniones registradas.

${ }^{45}$ Sobre el momento exacto en que se considera iniciado un procedimiento, vid. Art. 17 RB II ter (art. 16 RB II bis). Y para conocer la doctrina del TJUE acerca de cómo ha de interpretarse la expresión "desde el momento en que se le presente la demanda o documento equivalente [al órgano jurisdiccional]", vid. ATJUE de 22 de junio de 2016, M.H. y M.H, C-173/16 y ATJUE de 16 de julio de 2015, $P$, C-507/14), no publicado. 
Así, por ejemplo, si se presenta una demanda de modificación de medidas de responsabilidad parental establecidas por resolución firme dictada por los órganos jurisdiccionales de un Estado miembro, la presentación de la demanda de modificación debe considerarse el punto de partida de un nuevo procedimiento, y la competencia para conocer de esa demanda debe determinarse en atención a la residencia habitual del menor en ese momento ${ }^{46}$.

80. Una vez presentada la demanda, los cambios posteriores de residencia habitual del menor no alteran la competencia internacional ya determinada del tribunal. Rige aquí la regla de la perpetuatio iurisdictionis, en virtud de la cual resultan irrelevantes en la determinación del tribunal competente los cambios de residencia habitual del menor que sobrevengan una vez iniciado el proceso. En palabras del considerando 23 RB II ter, "para los procedimientos que ya están en curso, la seguridad jurídica y la eficiencia de la justicia justifican el mantenimiento de la competencia hasta que los procedimientos hayan desembocado en una resolución definitiva o hayan concluido de otra forma" ${ }^{47}$.

\section{B) Concepto de residencia habitual del menor a la luz de la jurisprudencia del TJUE}

81. El concepto de "residencia habitual del menor" es el concepto jurídico clave que utiliza el RB II ter para determinar la competencia en materia de responsabilidad parental. No solo constituye el fuero general sino que -como después veremos- en torno a este concepto giran todas las demás normas de competencia del Reglamento, de ahí la enorme importancia de conocer su significado. Sin embargo, como ya se ha dicho, el RB II ter no define este concepto, como, por otra parte, tampoco lo hace el Reglamento actualmente vigente en esta materia. Corresponde, pues, al órgano jurisdiccional que conoce del asunto determinar el lugar en que se encuentra la residencia habitual del menor a la vista de las circunstancias particulares de cada caso.

82. Ante la ausencia de una definición y la variedad de circunstancias fácticas particulares de cada caso, han sido muchos los órganos jurisdiccionales que, suspendiendo el curso del proceso planteado ante ellos, han elevado al TJUE - como garante de la interpretación uniforme de las normas comunitarias-sus dudas de interpretación acerca del concepto de "residencia habitual del menor" ${ }^{\text {" }}$. Gracias al planteamiento de estas cuestiones prejudiciales contamos hoy con una abundante doctrina jurisprudencial del TJUE sobre la interpretación que ha de darse a este concepto, a los efectos del RB II bis; doctrina que resulta plenamente aplicable al nuevo instrumento jurídico de la Unión Europea en materia de responsabilidad parental.

83. Antes de pasar a examinar las concretas resoluciones en las que el TJUE se ha pronunciado expresamente sobre la interpretación que ha de darse al concepto de residencia habitual del menor, con-

${ }^{46}$ En este sentido se pronuncia la STJU de 15 de febrero de 2017, W,Vy X, C-499/15: “ (...) los órganos jurisdiccionales de un Estado miembro que han adoptado una resolución firme en materia de responsabilidad parental (...) en lo que respecta a un menor de edad, no siguen siendo competentes para conocer de una demanda de modificación de las medidas establecidas en esa resolución en el caso de que la residencia habitual del menor esté situada en el territorio de otro Estado miembro. Los órganos jurisdiccionales competentes para conocer de esa demanda son los órganos jurisdiccionales de este último Estado miembro".

${ }^{47}$ No obstante, como se verá más adelante, el órgano jurisdiccional competente para conocer del fondo del asunto ante el que se esté sustanciando el procedimiento está facultado en determinadas circunstancias para transferir la competencia a un órgano jurisdiccional del Estado miembro al que el menor se hubiese trasladado lícitamente después de la presentación de la demanda y en el que hubiese adquirido su residencia habitual (arts. 12 y 13 RB II ter). Vid. infra, V. 4 y 5.

${ }^{48}$ Con frecuencia, los órganos jurisdiccionales que han planteado cuestiones prejudiciales al TJUE en materia de responsabilidad parental han solicitado que sus peticiones se tramiten por el procedimiento de urgencia previsto en el art. 107 del Reglamento de Procedimiento del Tribunal de Justicia y, en la mayoría de las ocasiones, el TJUE ha accedido a esta solicitud, especialmente en aquellos casos en que el litigio afecta a menores de corta edad que no tienen comunicación alguna con uno de los progenitores, pues, en estos casos, cualquier retraso en la sustanciación del proceso resulta perjudicial para el interés superior del menor. Y en los pocos casos en que el Tribunal no ha accedido a la solicitud, sí ha acordado dar a la petición de decisión prejudicial un tratamiento prioritario con arreglo al art. 53.3 del citado Reglamento. Es elogiable la apuesta procesal de la protección de interés del menor a través de la aplicación del procedimiento de urgencia, que, a mi juicio, debe ser decisión habitual. 
viene subrayar algunas de las cuestiones que el Tribunal de Luxemburgo repite con insistencia prácticamente en todas sus resoluciones sobre la materia, a saber:

84. $1^{\text {a) }}$ Puesto que el Reglamento no contiene una remisión expresa al ordenamiento jurídico de los Estados miembros para determinar el sentido y alcance del concepto de "residencia habitual del menor", dicho concepto debe ser objeto en toda la Unión Europea de una interpretación autónoma y unifor$m e$, a la vista del contexto y del objetivo del Reglamento, en especial, del que resulta de su considerando 12 -ahora, considerandos 19 y 20 RB II ter-, según el cual las normas de competencia en materia de responsabilidad parental están concebidas en función del interés superior del menor, y, en particular, en función del criterio de proximidad.

85. $2^{\mathrm{a}}$ ) La jurisprudencia del TJUE relativa al concepto de residencia habitual en otros ámbitos del Derecho de la Unión Europea no puede trasladarse directamente al marco de la apreciación de la residencia habitual del menor en el sentido del Reglamento que ahora nos ocupa.

86. $3^{\text {a }}$ ) La residencia habitual del menor debe determinarse sobre la base de un conjunto de circunstancias de hecho que son particulares en cada caso, y compete a los órganos jurisdiccionales nacionales determinar dónde está el lugar de residencia habitual del menor teniendo en cuenta un abanico de elementos fácticos concordantes.

87. Junto a estas consideraciones generales, el TJUE, en las numerosas resoluciones que ha dictado en estos más de quince años de vigencia del RB II bis, ha fijado algunos criterios que sirven para determinar el concepto de "residencia habitual del menor". Estos criterios delimitadores conforman lo que se denomina la interpretación autónoma o propia del concepto jurídico de "residencia habitual del menor" que todo tribunal miembro de la Unión Europea debe realizar, garantizándose así la uniformidad de aplicación y la preeminencia de las normas comunitarias.

88. Por otra parte, hay que señalar que los elementos que definen el concepto de "residencia habitual del menor" son los mismos, cualquiera que sea la disposición del Reglamento aplicable. Como ha dicho el TJUE, el concepto de "residencia habitual del menor" que emplea el Reglamento no puede tener un contenido diferente en función de la disposición que resulte aplicable, sino que debe tener un significado uniforme en todo el Reglamento, resulte de aplicación la norma de competencia general, la de competencia en caso de traslado o retención ilícitos de un menor o cualquier otra ${ }^{49}$.

89. Así pues, parece oportuno ahora, al hilo del fuero general y antes de pasar a examinar el resto de fueros del Reglamento, exponer los criterios delimitadores del concepto de "residencia habitual del menor" a efectos del presente Reglamento.

\section{a) Integración del menor en un entorno social y familiar}

90. La primera cuestión prejudicial planteada ante el TJUE sobre la interpretación del concepto de "residencia habitual del menor", a propósito del RB II bis, se refiere a una situación en la que el domicilio fijo de los menores estaba situado en un Estado miembro (Suecia), pero residían en otro (Finlandia), en el que llevaban una vida errante, viviendo en caravanas en diversos campings y sin estar escolarizados. El Tribunal de Justicia, en la sentencia de 2 de abril de 2009, A, C-523/07, hace algunas declaraciones importantes sobre este concepto, que encontramos repetidas hasta la saciedad en sentencias posteriores y que, creo, merece la pena reproducir. Así, según se dice en esta sentencia, para determinar la residencia habitual del menor:

${ }^{49}$ Vid. STJUE de 9 de octubre de 2014, C y M, C-376/14 PPU, y STJUE de 8 de junio de 2017, OL y PQ, C-111/17 PPU. 
“Además de la presencia física del menor en un Estado miembro, deben tenerse en cuenta otros factores que puedan indicar que dicha presencia no tiene en absoluto carácter temporal u ocasional y que la residencia del menor se traduce en una determinada integración en un entorno social y familiar.

En particular, han de tenerse en cuenta la duración, la regularidad, las condiciones y las razones de la permanencia en el territorio de un Estado miembro y del traslado de la familia a dicho Estado, la nacionalidad del menor, el lugar y las condiciones de escolarización, los conocimientos lingüísticos y las relaciones familiares y sociales del menor en dicho Estado.

(...) la intención de los padres de establecerse con el menor en otro Estado expresada a través de circunstancias externas, como la compra o alquiler de una vivienda en el Estado miembro de destino, pueden ser un indicio del traslado de la residencia habitual. Otro indicio puede estar constituido por la solicitud de una vivienda social presentada ante los servicios competentes del referido Estado.

Por el contrario, el hecho de que los menores permanezcan en un Estado miembro en el que llevan una vida errante durante un corto periodo de tiempo puede ser un indicio de que los menores no tiene su residencia habitual en ese Estado".

\section{b) Duración de la estancia}

91. El TJUE se pronunció de nuevo sobre el concepto de "residencia habitual de menor" en sentencia de 22 de diciembre de 2010, Mercredi, C-497/10 PPU, a raíz de una petición de decisión prejudicial planteada por la Court of Appeal (England \& Wales) (Civil Division) (Reino Unido), en el marco de un litigio entre el Sr. Chaffe, padre de una menor lactante, y la Sra. Mercredi, madre de la niña, sobre el derecho de custodia de la menor, a la que con dos meses de vida su madre había trasladado desde Inglaterra, donde consta que estaba la residencia habitual de la niña antes de su salida hacia la isla de Reunión (Francia), lugar de nacimiento de la madre y donde la niña se encuentra en el momento en que el tribunal remitente plantea la cuestión prejudicial. También consta que el traslado de la niña a la isla de Reunión era lícito, pues, cuando tuvo lugar, la madre era la única persona que disponía de un "derecho de custodia" a los efectos del Reglamento.

92. En esta resolución, el TJUE, después de reiterar la doctrina de la sentencia anterior (asunto A), se pronuncia en los siguientes términos sobre el peso de la duración de la estancia a la hora de determinar la residencia habitual del menor:

"Se debe poner de relieve al respecto que para distinguir la residencia habitual de una mera presencia temporal, la referida residencia debe ser en principio de cierta duración, para que revele una estabilidad suficiente. El Reglamento no prevé sin embargo una duración mínima. En efecto, para el traslado de la residencia habitual al Estado miembro de acogida importa ante todo la voluntad del interesado de fijar en ese Estado el centro permanente o habitual de sus intereses con la intención de conferirle un carácter estable. Así pues, la duración de una estancia solo puede servir como indicio en la evaluación de la estabilidad de la residencia, que debe realizarse a la luz de la totalidad de las circunstancias de hecho específicas de cada caso".

\section{c) La edad del menor: residencia habitual de un menor lactante}

93. En la sentencia anterior (asunto Mercredi), el TJUE declara también que la edad del menor puede revestir además una importancia especial. En concreto, cuando el menor es un lactante, el Tribunal de Justicia señala que su entorno es, en esencia, un entorno familiar, determinado por la persona o personas de referencia con las que vive a diario - por norma general, sus padres-, que lo guardan efectivamente y cuidan de él, y que comparte necesariamente el entorno social y familiar de esa o esas personas. En este sentido, puede leerse lo que sigue:

"En efecto, el entorno social y familiar del menor, esencial para la determinación del lugar de su residencia habitual, se compone de diferentes factores, variables según la edad del menor. De esa forma, los 
factores que deben considerarse en el caso de un menor en edad escolar difieren de los que hay que valorar si se trata de un menor que haya terminado sus estudios, o de los pertinentes en relación con un lactante.

Como regla general, el entorno de un menor de corta edad es en esencia un entorno familiar, determinado por la persona o las personas de referencia con las que vive el menor, que lo guardan efectivamente y cuidan de él.

Ello sucede así a fortiori cuando el menor afectado es un lactante. Éste comparte necesariamente el entorno social y familiar de la o las personas de las que depende. En consecuencia, cuando, como ocurre en el asunto principal, el lactante está efectivamente bajo la guardia de su madre, debe evaluarse la integración de esta en su entorno social y familiar. En ese aspecto pueden tenerse en cuenta los criterios enunciados por la jurisprudencia del Tribunal de Justicia, como las razones del traslado de la madre del menor a otro Estado miembro, los conocimientos lingüísticos de ésta o también sus orígenes geográficos y familiares.

De cuanto precede se deduce que procede responder a la primera cuestión que el concepto de «residencia habitual» a efectos de los artículos 8 y 10 del Reglamento (CE) nº 2201/2003 (...) debe interpretarse en el sentido de que esa residencia corresponde al lugar que revela una cierta integración del menor en un entorno social y familiar. A tal fin, y cuando se trata de la situación de un lactante que se encuentra con su madre tan sólo desde algunos días antes en un Estado miembro distinto del de su residencia habitual, al que ha sido trasladado, deben considerarse en especial la duración, la regularidad, las condiciones y las razones de la estancia en el territorio de ese Estado miembro y del traslado de la madre a este último Estado, por una parte, y por otra, a causa en particular de la edad del menor, los orígenes geográficos y familiares de la madre, así como las relaciones familiares y sociales que mantienen ésta y el menor en el mismo Estado miembro. Incumbe al órgano jurisdiccional nacional determinar la residencia habitual del menor teniendo en cuenta la totalidad de las circunstancias de hecho específicas de cada caso" ${ }^{50}$.

\section{d) Presencia física del menor}

94. La STJUE de 15 de febrero de 2017, $W, V$ y $X$, C-499/15, contiene una declaración que no por elemental está de más, a saber: la presencia física del menor en un Estado miembro es un requisito previo para demostrar la residencia en dicho Estado. En palabras del TJUE: "la determinación de la residencia habitual de un menor en un Estado miembro requiere, como mínimo, que el menor haya estado físicamente presente en ese Estado miembro. El mero hecho de que una de las nacionalidades del menor sea la de dicho Estado miembro no basta para considerar que este menor tenga en él su residencia habitual, en el sentido del Reglamento".

95. $\mathrm{Y}$ esta misma exigencia acerca de la presencia física del menor en un Estado miembro para determinar su residencia habitual en él ha sido reiterada en sentencia de 17 de octubre de 2018, UD y XB, C-393/18 PPU, en la que el Tribunal declara que "el art. 8.1 del Reglamento $n^{\circ}$ 2201/2003 debe interpretarse en el sentido de que un menor debe haber estado físicamente presente en un Estado miembro para que pueda considerarse que reside habitualmente en él, en el sentido de esta disposición”. El Tribunal europeo hace esta declaración en un caso como el del litigio principal en el que la madre fundamentaba la competencia del órgano jurisdiccional remitente [Tribunal Superior de Justicia (Inglaterra y Gales), División de familia, Reino Unido] en la residencia habitual del menor, a pesar de que este nunca había estado presente en ese Estado miembro. Para el TJUE, "circunstancias como las controvertidas en el litigio principal, en caso de quedar demostradas -a saber, por un lado, presiones ejercidas por el padre sobre la madre, que tuvieron como consecuencia que esta diera a luz a la menor en un Estado tercero y permaneciera en dicho Estado desde su nacimiento, y, por otro lado, la vulneración de los derechos fundamentales de la madre o de la menor-, carecen de pertinencia a este respecto"s1.

\footnotetext{
50 Sobre el concepto de residencia habitual de un menor lactante ha vuelto a pronunciarse el TJUE en sentencia de 8 de junio de 2017, OL y PQ, C-111/17 PPU y sentencia de 28 de junio de 2018, HR, C-512/17.

${ }^{51}$ L.A. PÉrez MarTín realiza un interesante comentario de esta sentencia del TJUE ("Residencia habitual de los menores y vulneración de derechos fundamentales", en La Ley Unión Europea n ${ }^{\circ}$ 66, enero 2019). Vid., también B. CAMpuZANo DíAz, "Una nueva sentencia del TJUE sobre el concepto de residencia habitual en el marco del Reglamento 2201/2003: sentencia de
} 


\section{e) La intención de los padres de establecerse con el menor en un Estado miembro}

96. El TJUE, en sentencia de 8 de junio de 2017, $O L$ y $P Q$, C-111/17 PPU, se pronuncia sobre el peso de la intención de los padres como criterio para determinar el lugar de residencia habitual del menor. En esta sentencia, el Tribunal de Justicia resuelve una petición de decisión prejudicial planteada por el Juzgado de Primera Instancia de Atenas (Grecia), en relación con una demanda presentada por el padre en la que solicita la restitución de la menor -que se haya en Grecia, Estado miembro en el que nació, por voluntad común de sus padres, y en el que permanece con su madre- a Italia, donde se encontraba la residencia habitual de la pareja antes del nacimiento de la niña, y donde inicialmente era intención común de los padres que regresara la madre con la menor.

97. Al hilo de este asunto, el Tribunal de Justicia declara que la intención de los padres de establecerse con el menor en un Estado miembro no puede, en principio, ser decisiva por sí sola para determinar la residencia habitual de un menor, pero constituye un indicio que puede venir a completar un abanico de otros elementos concordantes ${ }^{52}$. Obviamente, el peso que quepa acordar al anterior criterio con el fin de determinar el lugar de residencia habitual del menor dependerá de las circunstancias propias de cada caso. Según el Tribunal de Justicia, "adoptar como criterio preponderante la intención inicial de los progenitores de que la madre regresase a acompañada de la menor a un segundo Estado miembro, que era el de la residencia habitual de aquellos antes del nacimiento de la menor, estableciendo con ello de hecho una regla general y abstracta de que la residencia habitual de un lactante es necesariamente la de sus padres, iría más allá de los límites del concepto de residencia habitual, en el sentido del Reglamento $\mathrm{n}^{\mathrm{o}}$ 2201/2003, y sería contrario a la lógica interna, a la eficacia y a la finalidad del procedimiento de restitución".

98. La STJUE de 28 de junio de 2018, HR, C-512-17, vuelve a insistir en que la determinación del lugar en que se sitúa la residencia habitual del menor, en el sentido del Reglamento $n^{\circ}$ 2201/2003, se basa esencialmente en circunstancias objetivas y que, por tanto, la intención de los padres no es por sí sola decisiva a estos efectos.

\section{f) Prevalencia de las consideraciones objetivas sobre los vínculos de carácter cultural del menor respecto a un Estado miembro y su nacionalidad}

99. En el mismo asunto anterior, (asunto $H R$ ), el TJUE declara que para interpretar el concepto de residencia habitual del menor no puede concederse una importancia preponderante a los vínculos de carácter cultural del menor o a su nacionalidad en perjuicio de consideraciones geográficas objetivas, a menos que se pase por alto la intención del legislador de la Unión. Para el TJUE, los orígenes geográficos del progenitor que ejerce efectivamente la guarda y custodia del menor y las relaciones que el menor mantiene con los miembros de su familia residentes en dicho Estado, así como el hecho de que la menor comparta la cultura de dicho Estado -lo que pone de manifiesto, en particular, la lengua en la que se expresa principalmente y el hecho de que fue bautizada en ese Estado- no pueden ocultar, a efectos de determinar el lugar en que está situado el centro de vida del menor, las circunstancias objetivas que indican que este residía de manera estable con dicho progenitor en otro Estado miembro en la fecha de interposición de la demanda relativa a la responsabilidad parental. En palabras del TJUE "constituyen, conjuntamente, circunstancias determinantes: el hecho de que el menor haya residido, desde su nacimiento hasta la separación de sus padres, generalmente con ellos en un lugar determinado; la circunstancias

\footnotetext{
17 de octubre de 2018, UD y XB, AS. 393/18 PPU”, en Cuadernos de Derecho Transnacional (Octubre 2019), Vol. 11, № 2, pp. 462-471.

${ }^{52}$ Según el TJUE, la intención de los padres de establecerse con un menor en un Estado miembro determinado puede tomarse en cuenta cuando se expresa a través de determinadas circunstancias externas, como la compra o el alquiler de una vivienda en el Estado miembro de destino (cfr. STJUE de 2 de abril de 2009, A, C-523/07).
} 
de que el progenitor que, desde la separación de la pareja, ejercer en la práctica la guarda y custodia del menor siga residiendo a diario con este y ejerza en ese lugar su actividad profesional en una relación laboral por tiempo indefinido, y el hecho de que el menor mantenga, en dicho lugar, un contacto regular con su otro progenitor, que sigue residiendo en ese mismo lugar. En cambio, (...) no se pueden considerar circunstancias determinantes: las estancias que el progenitor que ejerce en la práctica la guarda y custodia del menor ha efectuado, en el pasado, con este, en el territorio del Estado miembro del que es nacional dicho progenitor en el marco de sus permisos parentales o periodos festivos; los orígenes del progenitor de que se trata, los vínculos de índole cultural del menor respecto a dicho Estado miembro derivados de tales orígenes y sus relaciones con su familia residente en dicho Estado miembro, y la eventual intención de dicho progenitor de establecerse con el menor, en el futuro en ese mismo Estado miembro".

\section{C) Los demás fueros del RB II ter}

100. El fuero de la residencia habitual del menor es el fuero general pero no el único del RB II ter que sirve para determinar el tribunal internacionalmente competente en el espacio judicial europeo en materia de responsabilidad parental. Este fuero, enunciado en el art. 7, debe completarse con el resto de normas de competencia de la Sección 2 del Capítulo II del Reglamento (arts. 8 a 16), que se analizan a continuación. Como veremos, algunos de estos fueros desplazan al fuero general (arts. 8, 9, y 10); uno tiene carácter subsidiario (art. 11), otro solo se aplica de forma residual (art. 14), y los demás, sencillamente, están al margen del fuero general (arts. 12 y 13). Por último, los arts. 15 y 16 establecen un fuero de competencia para la adopción de medidas cautelares y para la resolución de cuestiones incidentales, respectivamente.

\section{a) Mantenimiento de la competencia en relación con los derechos de visita}

101. Como regla, cuando un menor se traslada de un Estado miembro a otro -cuando aún no hay procedimientos en curso- la competencia debe seguirle, con el fin de mantener el criterio de proximidad y así salvaguardar el interés superior del menor. Por tanto, desde el momento en que el menor cambie de residencia de un Estado a otro y adquiera una nueva residencia habitual en dicho Estado, los órganos jurisdiccionales del nuevo Estado miembro serán competentes en materia de responsabilidad parental respecto del menor, por aplicación de la norma general de competencia del art. 7.1 RB II ter.

102. No obstante, a menudo en estos casos de cambio de residencia es necesario revisar el derecho de visita para adaptarlo a las nuevas circunstancias. En caso de que los progenitores no convengan los ajustes necesarios del derecho de visita y el titular de ese derecho se vea abocado a acudir a los órganos jurisdiccionales, el art. 8.1 RB II ter, bajo ciertas condiciones, otorga competencia en relación con el derecho de visita a los órganos jurisdiccionales del Estado miembro en el que residía habitualmente el menor antes del cambio de residencia ${ }^{53}$.

103. Las condiciones que impone el art. 8.1 RB II ter para que los órganos jurisdiccionales del Estado miembro de la anterior residencia habitual del menor mantengan su competencia en relación con los derechos de visita son las siguientes:

104. $1^{\text {a }}$ ) El cambio de residencia habitual del menor tiene que ser legal. El art. 8.1 RB II ter no se aplica en caso de traslado o retención ilícitos de un menor (en ese caso, entra en juego el art. 9 RB II ter). Para determinar el carácter lícito o ilícito del traslado o retención hay que estar a la definición de este concepto del art. 2.2.11) RB II ter.

${ }^{53}$ El art. 8 RB II ter se corresponde con el art. 9 RB II bis, según la tabla de correspondencias que figura en el Anexo X. 
105. $2^{\mathrm{a}}$ ) El derecho visita que se quiere modificar tiene que haber sido adquirido por resolución previa dictada por los órganos jurisdiccionales del Estado miembro de la anterior residencia habitual del menor.

106. $3^{\mathrm{a}}$ ) Los órganos jurisdiccionales del Estado miembro de la anterior residencia habitual del menor solo mantienen su competencia en relación con los derechos de visita durante los tres meses siguientes al cambio de residencia ${ }^{54}$. Transcurrido este plazo, la pierden. El plazo de tres meses empieza a contar desde el momento en que se produce el traslado y la llegada del menor al nuevo Estado miembro.

107. $4^{\text {a }}$ ) El menor debe haber adquirido la residencia habitual en el nuevo Estado miembro durante el periodo de tres meses desde que tuvo lugar el traslado. Si después de tres meses desde el traslado el menor aún sigue teniendo su residencia habitual en el Estado miembro de origen, los órganos jurisdiccionales de ese Estado siguen siendo competentes, de conformidad con el art. 7.1 RB II ter. Corresponde al órgano jurisdiccional determinar en cada caso si un menor tiene o no su residencia habitual en un Estado miembro basándose en los hechos aplicables a la situación concreta de ese menor. Aunque del adjetivo habitual puede inferirse la exigencia de cierta duración de la residencia para que esta pueda calificarse de habitual, no ha de descartarse la posibilidad de que un menor adquiera su residencia habitual en el nuevo Estado miembro el mismo día de su llegada, o poco después.

108. $5^{\text {a) }}$ El titular del derecho de visita debe continuar residiendo habitualmente en el Estado miembro de la anterior residencia habitual del menor.

109. En principio, si concurren estas cinco condiciones, los órganos jurisdiccionales del Estado miembro en el que residía habitualmente el menor antes del cambio legal de residencia de un Estado a otro seguirán siendo competentes en relación con los derechos de visita respecto de ese menor. De esta forma se garantiza que el titular del derecho de visita pueda seguir acudiendo a los órganos jurisdiccionales de su Estado miembro de residencia habitual durante los tres meses siguientes al desplazamiento del menor al nuevo Estado.

110. No obstante, según el apartado 2 del art. 8 RB II ter, lo previsto en el aptado 1 "no se aplicará si el titular del derecho de visita a que se refiere el apartado 1 ha aceptado la competencia de los órganos jurisdiccionales del Estado miembro de la nueva residencia habitual del menor al participar en un procedimiento ante dichos órganos sin impugnar su competencia". Esta disposición no hace sino añadir una sexta condición a las anteriores, a saber: el titular del derecho de visita no debe haber aceptado el cambio de competencia. Y se entiende que el titular del derecho de visita acepta la competencia de los órganos jurisdiccionales del Estado miembro de la nueva residencia habitual del menor si participa en un procedimiento ante dichos órganos sin impugnar la competencia (sumisión tácita). En tal caso, el art. 8.1 RB II ter no se aplica y el órgano jurisdiccional del nuevo Estado miembro ejerce su competencia en virtud del art. 7.1 RB II ter. Po consiguiente, el art. 8 RB II ter no impide que el titular del derecho de visita acuda a los órganos jurisdiccionales del nuevo Estado miembro para examinar la cuestión del derecho de visita.

111. Nótese, además, que el mantenimiento de la competencia de los órganos jurisdiccionales de la anterior residencia habitual del menor solo alcanza a los derechos de visita, pero no a otras cuestiones propias de la responsabilidad parental (p. ej. el derecho de custodia). Por tanto, el art. 8 RB II ter no impide que durante los tres meses siguientes al cambio de residencia, el titular de la responsabilidad parental que se haya trasladado con el menor al nuevo Estado miembro acuda a los órganos jurisdiccionales de dicho Estado con cualquier otra demanda en materia de responsabilidad parental.

\footnotetext{
${ }^{54}$ Según el Consejo de la Abogacía Europea (CCBE), “este periodo de tres meses no es suficientemente largo. La extensión del período a seis meses sería oportuna. Permitiría verificar que el derecho de visita y de alojamiento es correctamente aplicado" (Informe del CCBE sobre la propuesta de la Comisión de revisión del Reglamento Bruselas II bis, 02/12/2016).
} 


\section{b) Competencia en caso de traslado o retención ilícitos de un menor}

112. Aunque la materia de sustracción internacional de menores, regulada en el Capítulo III del RB II ter queda fuera del objeto de este trabajo, creo oportuno examinar, siquiera brevemente, la norma de competencia en caso de traslado o retención ilícitos de un menor del art. 9 RB II ter, incluida en la Sección 2 del Capítulo II dedicada a las normas de competencia en materia de responsabilidad parental ${ }^{55}$.

113. Con respecto a esta materia, cabe señalar que el Reglamento pretende impedir la sustracción de menores entre Estados miembros y, en caso de sustracción, conseguir que la restitución del menor se produzca sin demora. De ello se sigue que la sustracción ilícita de un menor no debería, en principio, tener la consecuencia de transferir la competencia de los órganos jurisdiccionales del Estado miembro en el que residía habitualmente el menor inmediatamente antes de su traslado a los del Estado miembro al que el menor ha sido trasladado, ni siquiera en el supuesto de que, a raíz del traslado, el menor haya adquirido una residencia habitual en este último.

114. Para evitar este traslado de competencia, el art. 9 RB II ter garantiza que, en caso de traslado o retención ilícitos de un menor, los órganos jurisdiccionales del Estado miembro en el que el menor tenía su residencia habitual inmediatamente antes del traslado o retención mantengan o conserven su competencia para conocer del fondo del asunto también a partir de ese momento. Los órganos jurisdiccionales del Estado miembro al que el menor ha sido trasladado o en el que se encuentra retenido de forma ilícita solo adquieren competencia en dos situaciones que, según el TJUE, procede interpretar de manera restrictiva ${ }^{56}$, a saber:

115. $1^{\text {a }}$ ) El menor ha adquirido una residencia habitual en ese Estado miembro y el titular del derecho de custodia ha dado su conformidad al traslado o a la retención.

116. $2^{\text {a }}$ El menor ha adquirido una residencia habitual en ese Estado miembro, ha residido en él durante un periodo mínimo de un año desde que el titular del derecho de custodia ha tenido o hubiera debido tener conocimiento del paradero del menor, está integrado en su nuevo entorno y, además, se cumple alguna de las siguientes condiciones:

“i) En el plazo de un año desde que el titular del derecho de custodia ha tenido o hubiera debido tener conocimiento del paradero del menor, no se ha presentado ninguna demanda de restitución ante las autoridades competentes del Estado miembro en el que se encuentra el menor.

ii) El titular del derecho de custodia presentó una demanda de restitución pero desistió y no se ha presentado una nueva demanda dentro de ese año.

iii) Un órgano jurisdiccional de un Estado miembro ha denegado una demanda de restitución presentada por el titular del derecho de custodia por motivos distintos de los contemplados en el artículo 13, apartado 1, letra b), o el artículo 13, apartado 2, del Convenio de La Haya de 1980 y la resolución ya no es susceptible de recurso ordinario.

iv) No se ha acudido a ningún órgano jurisdiccional según lo dispuesto en el artículo 29, apartados 3 y 5 , en el Estado miembro en el que el menor tenía su residencia habitual inmediatamente antes de su traslado o retención ilícitos.

v) Los órganos jurisdiccionales del Estado miembro en el que el menor tenía su residencia habitual inmediatamente antes de su traslado o retención ilícitos han dictado una resolución sobre los derechos de custodia que no implica la restitución del menor"57.

${ }^{55} \mathrm{El}$ art. 9 RB II ter se corresponde con el art. 10 RB II bis, según la tabla de correspondencias que figura en el Anexo X.

${ }^{56}$ Cfr. STJUE de 1 de julio de 2010, Povse, C-211/10 y STJUE de 10 de abril de 2018, CV y DU, C-85/18 PPU.

${ }^{57}$ El TJUE ha declarado que esta condición debe interpretare de manera restrictiva. Así, ha sostenido que "una «resolución sobre la custodia que no implique la restitución del menor» es una resolución definitiva, adoptada sobre la base de un examen completo del conjunto de elementos pertinentes, mediante la cual el órgano jurisdiccional competente se pronuncia sobre la custodia del menor y que no está ya sujeta a otras resoluciones administrativas o judiciales (...). Por tanto, una medida provisional sobre la custodia del menor no constituye una «resolución sobre la custodia que no implique la restitución del menor», y 
117. Tal y como señala el propio art. 9 RB II ter, esta norma de competencia en caso de traslado o retención ilícitos de un menor se aplica "sin perjuicio del artículo 10", esto es, dejando a salvo la posibilidad de elección del órgano jurisdiccional por las partes. Aunque poco probable, cabe que las partes convengan libremente o acepten expresamente la competencia de los órganos jurisdiccionales del Estado miembro al que el menor ha sido trasladado o en el que se encuentra retenido de forma ilícita.

\section{c) Elección del órgano jurisdiccional}

118. El art. 10 RB II ter, bajo la rúbrica "Elección del órgano jurisdiccional" reconoce cierta autonomía a las partes en materia de responsabilidad parenta $l^{58}$. En este precepto, el Reglamento admite que, bajo ciertas condiciones, las partes pueden atribuir competencia para conocer de un litigio en materia de responsabilidad parental a los órganos jurisdiccionales de un Estado miembro en el que el menor no tiene su residencia habitual.

119. Antes de pasar a examinar las condiciones o requisitos que el Reglamento impone para la elección de foro, resulta oportuno advertir que el art. 10 RB II ter no condiciona en absoluto la elección de foro a que el procedimiento en materia de responsabilidad parental tenga conexión con otro procedimiento que esté pendiente ante el tribunal al que se pretende atribuir la competencia por elección. En este punto, el RB II ter, a diferencia de su predecesor, el RB II bis, no deja lugar a ninguna duda.

120. En efecto, el art. 12 del RB II bis distingue dos situaciones distintas en relación con la denominada "prórroga de la competencia" en materia de responsabilidad parental: de un lado, el aptdo. 1 contempla la posibilidad de prorrogar la competencia en favor de "los órganos jurisdiccionales del Estado miembro en que se ejerza la competencia con arreglo al artículo 3 en una demanda de divorcio, separación judicial o nulidad matrimonial", y, de otro lado, el aptdo. 3 prevé la prórroga de competencia en favor de los órganos jurisdiccionales de un Estado miembro "en procedimientos distintos de los contemplados en el apartado 1". Así las cosas, el RB II bis plantea la duda de si esta disposición permite o no fundamentar la competencia de un tribunal de un Estado miembro que no es el de la residencia habitual del menor, aun cuando no exista ningún otro procedimiento conexo pendiente ante el tribunal elegido.

121. Pues bien, sobre esta cuestión ya se ha pronunciado el TJUE en sentencia de 12 de noviembre de 2014, L y $M$, C-656/13, en el sentido de que para prorrogar la competencia no es necesario que el tribunal al que se pretende acudir esté ya conociendo de otro procedimiento. Para el Tribunal de Luxemburgo, circunscribir el ámbito de aplicación de esta disposición a los supuestos en los que el procedimiento en materia de responsabilidad parental tenga conexión con otro procedimiento ya pendiente "reduciría notablemente las posibilidades de aplicar la referida extensión de la competencia, teniendo en cuenta que la necesidad de incoar un procedimiento en materia de responsabilidad parental puede surgir con independencia de cualquier otro procedimiento", y "excluiría la posibilidad de aplicar la referida extensión de la competencia en numerosas situaciones, aun cuando la misma pudiera responder al interés superior del menor de que se trate".

no puede servir de fundamento para transferir la competencia a los órganos jurisdiccionales del Estado miembro al que el menor ha sido trasladado ilícitamente. Esta conclusión se desprende del sistema del Reglamento y responde también a los intereses del menor. En efecto, en el caso de que una resolución provisional condujera a la pérdida de la competencia sobre la cuestión de la custodia del menor, el órgano jurisdiccional competente del Estado miembro de la residencia habitual anterior del menor correría el riesgo de verse disuadido a adoptar tal decisión provisional, aun cuando los intereses del menor lo exigieran (STJUE de 1 de julio de 2010, Povse, C-211/10).

${ }^{58}$ Aunque con algunos cambios importantes, el art. 10 RB II ter mantiene la esencia del art. 12 RB II bis dedicado a la "prórroga de la competencia". Quizás sea precisamente por esos cambios por lo que no aparece la correspondencia entre estos dos preceptos en la tabla de correspondencias que figura en el Anexo X del nuevo Reglamento. 
122. El legislador europeo ha tenido en cuenta esta jurisprudencia del TJUE y la ha incorporado en el art. 10 RB II ter. En este precepto ya no se vincula en absoluto la elección de foro a la existencia de un proceso conexo pendiente ante los órganos jurisdiccionales del Estado miembro elegido, ni matrimonial ni de ningún otro tipo.

123. Las condiciones que impone el art. 10.1 RB II ter para la elección de foro son las siguientes:

124. a) Que el menor esté estrechamente vinculado al Estado miembro elegido, en especial, por el hecho de que: i) al menos, uno de los titulares de la responsabilidad parental tenga en ese Estado su residencia habitual; ii) dicho Estado es la antigua residencia habitual del menor, o iii) el menor es nacional de dicho Estado ${ }^{59}$.

125. b) Que las partes, así como cualquier otro titular de la responsabilidad parental: i) han convenido libremente en la competencia, al menos en el momento de presentar el asunto ante el órgano jurisdiccional; o ii) han aceptado expresamente la competencia durante dicho procedimiento y el órgano jurisdiccional se ha asegurado de que todas las partes han sido informadas de su derecho a no aceptar la competencia.

126. Con esta segunda condición se exige bien que exista, a más tardar en el momento en que se presenta la demanda, un acuerdo de elección de foro convenido libremente por las partes en favor de los órganos jurisdiccionales de un Estado miembro (pacto de sumisión expresa), bien que el demandado haya aceptado expresamente la competencia del órgano jurisdiccional elegido por el demandante durante dicho procedimiento, después de haber sido informado por el órgano jurisdiccional de su derecho a impugnar la competencia. Dada la sensibilidad de la materia que nos ocupa, el RB II ter quiere a toda costa evitar que una parte pueda aprovecharse de las dificultades o la vulnerabilidad de la otra y, por ello, no permite que el tribunal elegido por el actor pueda fundar su competencia en la sumisión tácita de las partes de una manera automática, por el solo hecho de que el demandado haya comparecido en el procedimiento sin impugnar la competencia. De ahí la nueva exigencia del RB II ter de que el órgano jurisdiccional, antes de asumir la competencia, se asegure de que se ha informado debidamente al demandado de su derecho a impugnar la competencia y de las consecuencias de no hacerlo ${ }^{60}$. En este caso, quizás, podría hablarse de una suerte de sumisión tácita confirmada o ratificada.

127. Se trata de una exigencia nueva en materia de responsabilidad parental que el RB II bis actualmente en vigor no impone, pero que no resulta extraña. El RB II ter no hace sino seguir en este punto lo que ya prevé el Reglamento (UE) nº $1215 / 2012$, en relación con la prórroga tácita de competencia en materia de seguros, contratos celebrados con consumidores y usuarios y contratos individuales de trabajo. En estas materias, habida cuenta de la necesidad de proteger a la parte "débil" de la relación jurídica, el Reglamento establece que el tribunal de un Estado miembro solo podrá fundar su competencia en la sumisión tácita de las partes si previamente se ha asegurado de que el demandado ha sido informado de su derecho a impugnar la competencia y de las consecuencias de comparecer o no ${ }^{61}$.

128. En cuanto a la forma, el acuerdo de elección de foro debe constar por escrito, fechado y firmado por las partes afectadas, o hacerlo constar en el acta judicial con arreglo al Derecho y el procedimiento nacionales. Se considerará realizada por escrito toda comunicación efectuada por medios electrónicos que proporcione un registro duradero del acuerdo (art. 10.2 párr. $1^{\circ} \mathrm{RB}$ II ter).

129. Por último, en relación con esta segunda condición, el párr. $2^{\circ}$ del art. 10.2 RB II ter indica que "las personas que pasen a ser partes en el procedimiento tras la presentación de la demanda

\footnotetext{
${ }^{59}$ Nótese que el hecho de que el legislador emplee la expresión “en especial” implica que la estrecha vinculación del menor con un Estado miembro puede obedecer a causas distintas de las tres expresamente previstas.

${ }^{60}$ Vid. Considerando 23 RB II ter.

${ }^{61}$ Cfr. art. 26 RB I bis.
} 
podrán dar su consentimiento con posterioridad. De no haber oposición expresa, se considerará que existe consentimiento implícito". Con esta disposición, el legislador europeo no hace más que acoger la doctrina sentada por el TJUE en sentencia de 19 de abril de 2018, Alessandro Saponaro, C-565/16, en la que se declara que en los procesos en los que, conforme al Derecho nacional, haya de intervenir como parte un fiscal en interés del menor, es preciso que el fiscal acepte la prórroga de competencia. En palabras de TJUE:

“(...) un fiscal que, según el Derecho nacional, es parte de pleno derecho en el procedimiento iniciado por los progenitores constituye una «parte en el procedimiento» (...). La oposición expresada por esa parte respecto a la elección del órgano jurisdiccional efectuada por los progenitores del menor después del momento en que se presentó el asunto ante el órgano jurisdiccional impide que pueda considerarse aceptada la prórroga de la competencia por todas las partes en el procedimiento en ese momento. A falta de tal oposición, puede considerarse que el consentimiento de dicha parte es implícito y que concurre el requisito de aceptación de la prórroga de la competencia de forma inequívoca por todas las partes en el procedimiento en el momento de presentar el asunto ante el órgano jurisdiccional $\rangle^{62}$.

130. En relación con el cumplimiento de este segundo requisito o condición, el TJUE se ha pronunciado en varias ocasiones. En sentido positivo, la sentencia anterior (asunto Alessandro Saponaro), afirma que se cumple con esta condición cuando los dos progenitores del menor presentan conjuntamente una solicitud ante el mismo órgano jurisdiccional. En sentido negativo encontramos varios pronunciamientos. Así, en sentencia de 12 de noviembre de 2014, L y M, C-656/13, el TJUE declara que no puede considerarse "aceptada expresamente" la competencia del tribunal ante el que una parte insta la sustanciación de un procedimiento en materia de responsabilidad parental "cuando la parte demandada en este primer procedimiento inicie posteriormente un segundo procedimiento ante el mismo tribunal y alegue, con ocasión de la primera actuación que le incumba en el primer procedimiento, la incompetencia del tribunal". Por su parte, la STJUE de 21 de octubre de 2015, Gogova, C-215/15, establece que la competencia de los tribunales para conocer de una demanda de responsabilidad parental presentada ante ellos no puede considerarse, en el sentido del art. 12.3 RB II bis, "aceptada expresamente" por el demandado ausente -al que no se ha notificado el escrito de demanda y que ignora el procedimiento-, "por el simple motivo de que el mandatario ad litem que representa al demandado, designado de oficio por esos tribunales ante la imposibilidad de notificar a este último el escrito de demanda, no haya alegado la falta de competencia de los citados tribunales". Y el ATJUE de 3 de octubre de 2019, OF y PG, C-759/18, señala que cuando un tribunal del Estado miembro de la nacionalidad común de los cónyuges, al que el demandante ha presentado una demanda de divorcio, es competente para pronunciarse en materia de divorcio en virtud del art. 3.1 b RB II bis, "no puede considerarse que concurra el requisito relativo a la aceptación de la competencia previsto en el art. $12.1 \mathrm{~b}$, desde el momento en que el procedimiento no tiene por objeto la responsabilidad parental y la parte demandada no ha comparecido. En tales circunstancias, el tribunal al que se ha sometido el asunto, que es competente para pronunciarse sobre el divorcio de los cónyuges, no lo es (...) para pronunciarse sobre cuestiones relativas a la responsabilidad parental y a la obligación de alimentos en favor del menor afectado".

131. c) Que el ejercicio de la competencia responde al interés superior del menor. El órgano jurisdiccional acordado o aceptado por las partes ha de cerciorarse, a la vista de las circunstancias concretas del asunto, de que el acuerdo de elección de foro responde al interés superior del menor. Así, en el asunto Alessandro Saponaro, anteriormente referido, en el que los dos progenitores de una menor y por cuenta de esta solicitan conjuntamente a un tribunal griego autorización para repudiar la herencia del abuelo materno de la menor fallecido en Grecia, a pesar de que ambos progenitores así como la menor tienen su residencia habitual en Italia, el TJUE considera que "la circunstancia de que la residencia del causante en el momento de su fallecimiento, su patrimonio, objeto de la sucesión, y el pasivo de la herencia estuvieran situados en el Estado miembro del órgano jurisdiccional elegido permite considerar,

${ }^{62}$ Vid., también, considerando 23 RB II ter. 
a falta de elementos que demuestren que la prórroga de la competencia podría incidir negativamente sobre la situación del menor, que tal prórroga de la competencia responde al interés superior del menor".

132. En estos casos de acuerdo entre las partes, puede resultar muy útil que el órgano jurisdiccional, de conformidad con lo previsto en el art. 21 RB II ter, dé al menor-siempre que tenga capacidad para formarse sus propios juicios- la posibilidad real y efectiva de expresar libremente su opinión y tenerla debidamente en cuenta a la hora de valorar el interés superior del menor, de acuerdo con su edad y madurez.

133. Nótese que estas tres condiciones han de concurrir de forma simultánea. Es preciso, por tanto, que la competencia acordada o aceptada por las partes se otorgue necesariamente a los órganos jurisdiccionales de un Estado miembro con el que el menor tenga una estrecha vinculación, y que el órgano jurisdiccional se cerciore, a la vista de las circunstancias específicas de cada caso, que la elección del órgano jurisdiccional respeta el interés superior del menor.

134. Con el fin de respetar la exigencia de proximidad para cualquier nuevo procedimiento en el futuro, el aptdo. 3 del art. 10 RB II ter establece que la competencia acordada o aceptada por las partes, a menos que estas acuerden otra cosa, cesará: a) en cuanto la resolución dictada en el procedimiento ya no sea susceptible de recurso ordinario; o b) en cuanto haya concluido el procedimiento por otro motivo.

135. Así pues, la prórroga de competencia surte efectos hasta que concluye el procedimiento que originó esa prórroga, pero esos efectos no se mantienen más allá. En este sentido ya se ha pronunciado expresamente el TJUE en sentencia de 1 de octubre de 2014, E. y B., C-436/13, en la que declara que "una prórroga de la competencia basada en el art. 12, apartado 3, del Reglamento $n^{\mathrm{o}}$ 2201/2003 únicamente es válida para el procedimiento específico incoado ante el órgano jurisdiccional cuya competencia se prorroga, y que esa competencia decae en favor del órgano jurisdiccional que ostenta una competencia general en virtud del art. 8, apartado 1, de dicho Reglamento, con la conclusión definitiva del procedimiento que motivó la prórroga de la competencia”. En concreto, para el TJUE la competencia prorrogada en favor de un órgano jurisdiccional de un Estado miembro ante el que los titulares de la responsabilidad parental han incoado de común acuerdo un procedimiento, "se extingue al recaer una resolución firme en el marco de dicho procedimiento" $"$.

136. El aptdo. 4 del art. 10 RB II ter termina señalando que "la competencia otorgada en el aptdo. 1, letra b), inciso ii, será exclusiva", lo que significa que este fuero excluye la aplicación de cualquier otra regla de competencia. Aunque esta disposición solo atribuya el carácter de exclusiva a la competencia otorgada en virtud del aptdo. 1, letra b), inciso ii del art. 10, que particularmente se refiere a la competencia aceptada expresamente por las partes durante el procedimiento, parece más razonable entender que la competencia se ejercerá con carácter exclusivo siempre que se haya determinado de conformidad con el art. 10 RB II ter, también cuando se trate de una competencia convenida libremente por la partes a la que se refiere el aptdo. 1, letra b) inciso i). Así se deduce del resto de normas del Reglamento que hacen referencia a la determinación de la competencia exclusiva del órgano jurisdiccional de conformidad con el art. 10 (arts. 12.5 y 20.4 y 5).

137. Deliberadamente, he dejado para el final una cuestión, ya apuntada, que no resulta fácil de resolver. Se trata de determinar si el art. 10 RB II ter solo resulta aplicable si el menor tiene su residencia habitual en un (otro) Estado miembro, o si se aplica también aun cuando el menor resida habitualmente en un tercer Estado. Como ya señalé, algunos autores sostienen, a propósito del RB II bis, cuyo art. 12 también prevé la prórroga de competencia en favor de los órganos jurisdiccionales de un Estado miembro en el que el menor no reside habitualmente, que la determinación de la competencia judicial con arreglo a los fueros del Reglamento solo es posible si el menor tiene su residencia habitual en un Estado

\footnotetext{
${ }^{63}$ En este mismo sentido, vid., STJUE de 12 de noviembre de 2014, L y M, C-656/13 y STJUE de 15 de febrero de 2017, $W, V y X, \mathrm{C}-499 / 15$.
} 
miembro. Si la tiene en un tercer Estado o no tiene una residencia habitual en ningún país concreto, el Reglamento, sencillamente, no es aplicable, y la determinación de la competencia tendrá que realizarse con arreglo al Convenio de La Haya de $1996^{64}$.

138. A mi juicio, sin embargo, se trata esta de una cuestión que merece la pena repensar. Desde luego, la aplicación del conjunto de normas de competencia en materia de responsabilidad parental del RB II ter está sujeta a que el menor tenga su residencia habitual en un Estado miembro. Me planteo, sin embargo, una única excepción: la norma de competencia del art. 10. Creo que la aplicabilidad del art. 10 no debe necesariamente condicionarse a que el menor tenga su residencia habitual en un Estado miembro de la Unión Europea -distinto de aquél en el que tiene su residencia habitual-; antes bien, puede sostenerse que el acuerdo de elección de foro opera aun cuando el menor resida habitualmente en un tercer Estado, siempre que las partes hayan convenido o aceptado expresamente la competencia, el menor tenga un vínculo estrecho con el Estado miembro elegido por las partes (p. ej. porque el menor es nacional de dicho Estado), y siempre que el ejercicio de la competencia responda al interés superior del menor $^{65}$. En definitiva, siempre que se cumplan las exigencias del art. 10.

139. Que un Reglamento resulte aplicable-rectius, algunas de sus normas-, aun cuando no concurra el requisito señalado por el Reglamento como criterio de delimitación espacial del mismo, es algo que no debe resultar extraño. En efecto, el Reglamento (UE) nº 1215/2012 (materia civil y mercantil), se aplica íntegramente si el demandado tiene su domicilio en un Estado miembro, y si el demandado no tiene su domicilio en un Estado miembro, aún así deben ser aplicadas, en todo caso, las normas que regulan las denominadas competencias exclusivas (art. 24); las que regulan la llamada prórroga de la competencia (arts. 25 y 26); y los arts. 18.1 y 21.2 en materia de consumidores y contratos de trabajo, respectivamente.

140. Nótese que uno de los fueros del RB I bis aplicable aunque el demandado tenga su domicilio en un Estado no comprendido en el ámbito espacial del Reglamento es, precisamente, el fuero de sumisión expresa. Según el art. 25 RB I bis, "si las partes, con independencia de su domicilio, han acordado que los órganos jurisdiccionales de un Estado miembro sean competentes para conocer (...), tales órganos jurisdiccionales serán competentes (...)". Y, de ordinario, la expresión "con independencia de su domicilio" de esta disposición se interpreta en el sentido de que este fuero es aplicable aun cuando el demandado tenga su domicilio en un Estado que no sea miembro de la Unión Europea.

141. Pues bien, en la materia que ahora nos ocupa, puede sostenerse también que el fuero de elección del órgano jurisdiccional del art. 10 RB II ter opera "con independencia de la residencia habitual del menor" o "sin consideración de la residencia habitual del menor", es decir, aunque el menor resida habitualmente en un tercer Estado. Como hemos visto, el legislador europeo prevé, como excepción al fuero general, la posibilidad de que las partes expresamente atribuyan competencia a los tribunales de un Estado miembro distinto del de la residencia habitual del menor solo si esa atribución de competencia responde al interés superior del menor. Lo verdaderamente relevante para la aplicación de esta norma es, pues, la protección del interés superior del menor como "consideración primordial" a tener en cuenta en todas las medidas que se tomen en relación con los niños, con independencia de donde tenga el menor su residencia habitual. Por tanto, si el órgano jurisdiccional de un Estado miembro al que han acudido libremente las partes considera que existe un vínculo estrecho entre el menor y el Estado miembro elegido, y que el ejercicio de su competencia responde al interés superior del menor podrá fundar su competencia en el fuero del art. 10 RB II ter, aunque el lugar de residencia habitual del menor esté en un tercer Estado $^{66}$. Y creo que esta conclusión vale tanto si el menor tiene su residencia habitual en el territorio de

\footnotetext{
64 Vid. A. L. Calvo Caravaca / J. Carrascosa González, Derecho Internacional Privado, Vol. II, cit., p. 485.

${ }^{65}$ Esta posición es sostenida por F. J. Garcimartín Alférez, Derecho Internacional Privado, Civitas, $3^{\mathrm{a}}$ ed., 2016 , p. 158.

${ }^{66}$ A esta misma conclusión se llega con el actual art. 12 RB II bis. De hecho, en la mayoría de los informes internacionales sobre el RB II bis elaborados por expertos se parte de esta consideración, esto es, de que si un menor tiene su residencia habitual
} 
un tercer Estado que no sea parte del Convenio de La Haya de 1996 como en un tercer Estado parte del Convenio ${ }^{67}$. Quizás, en relación con los terceros Estados que no son parte contratante del Convenio de La Haya, habría estado bien que el art. 10 RB II ter incluyera la previsión contenida en el actual art. 12 RB II bis de que en estos casos "se presumirá que la competencia basada en este artículo es en beneficio del menor, en especial cuando un procedimiento resulte imposible en el tercer Estado de que se trata".

142. A mayor abundamiento, el art. 14 RB II ter, que se analizará más adelante, establece una norma de competencia residual "si de los arts. 7 a 11 no se deduce la competencia de ningún órgano jurisdiccional de un Estado miembro", en cuya virtud la competencia se determinará con arreglo a la legislación de cada Estado miembro. Pues bien, si entendemos que el Reglamento solo se aplica respecto de menores que tienen su residencia habitual en un Estado miembro, esta norma resultaría inaplicable, pues siempre existiría un Estado miembro cuyos órganos jurisdiccionales serían competentes para conocer del fondo del asunto en virtud del art. 7.168. Creo, sin embargo, que esta norma puede estar pensada, precisamente, para supuestos en que el menor reside habitualmente en un tercer Estado y la competencia de los órganos jurisdiccionales de un Estado miembro tampoco puede determinarse con base en un acuerdo de elección de foro del art. 10. De ser así, el RB II ter sujeta la competencia a la legislación de cada Estado miembro.

\section{d) Competencia basada en la presencia del menor}

143. El art. 11 RB II ter atribuye la competencia a los órganos jurisdiccionales del Estado miembro en que esté presente el menor ${ }^{69}$. Se trata de una norma de competencia subsidiaria que solo entra en juego cuando no puede determinarse la residencia habitual del menor y tampoco puede determinarse la competencia sobre la base de un acuerdo de elección de foro del art. 10 RB II ter. En estos casos, la determinación del órgano jurisdiccional competente debe realizarse conforme al criterio de "la presencia del menor". Lógicamente, en caso de que el menor se encuentre en un tercer Estado, este foro no opera.

144. Nótese que este foro se activa cuando no puede determinarse la residencia habitual del menor, es decir, cuando el órgano jurisdiccional de un Estado miembro, atendidas todas las circunstancias de hecho particulares del caso, llega a la conclusión de que no puede identificarse la residencia habitual del menor ${ }^{70}$. Por tanto, la mera presencia del menor en un Estado miembro no es punto de conexión comunitaria suficiente para atribuir competencia judicial internacional a sus tribunales si la residencia habitual del menor está identificada en otro Estado: si el menor reside en otro Estado miembro, los tribunales de ese Estado serán los competentes por aplicación de la norma de competencia general del RB II ter (art. 7.1), y si el menor reside en un tercer Estado, la competencia se determinará con arreglo al Convenio de La Haya de 1996, sin perjuicio del art. 10 RB II ter.

145. Esta norma de competencia basada en la presencia del menor también debe aplicarse a los menores refugiados y a los desplazados internacionalmente a causa de disturbios ocurridos en su Estado miembro de residencia habitual ex art. 11.2 RB II ter. No obstante, esta norma solo debe aplicarse a los

en un tercer Estado, la tramitación de un procedimiento en materia de responsabilidad parental ante un tribunal de un Estado miembro solo será posible si los padres están de acuerdo (cfr. A. NuYTs, "Study on residual jurisdiction (Review of the Member States' Rules concerning the "Residual Jurisdiction" of their courts in Civil and Commercial Matters pursuant to the Brussels I and II Regulations)", General Report (final versión dated 3 September 2007), pp. 92-94.

${ }^{67}$ Nótese que el art. 10 del Convenio de La Haya contempla la prórroga de competencia de una forma mucho más limitada que el art. 10 RB II ter, solo en favor de las autoridades de un Estado contratante que estén conociendo de una demanda matrimonial.

${ }^{68}$ Coherente con su posición, en este sentido se pronuncia A. L. Calvo Caravaca / J. Carrascosa González (Derecho Internacional Privado, Vol. II, cit., p. 484), en relación con la norma de competencia residual del art. 14 RB II bis.

${ }^{69} \mathrm{El}$ art. $11 \mathrm{RB}$ II ter se corresponde con el art. $13 \mathrm{RB}$ II bis, según la tabla de correspondencias que figura en el Anexo X.

${ }^{70}$ Cfr. STJUE de 22 de diciembre de 2010, Mercredi, C-497/10 PPU. 
menores que antes del desplazamiento tuvieran su residencia habitual en un Estado miembro. Si la residencia habitual del menor antes del desplazamiento se encontraba en un tercer Estado, debe aplicarse la norma de competencia relativa a los menores refugiados e internacionalmente desplazados que figura en el art. 6 del Convenio de La Haya de 1996 que, al igual que el Reglamento, atribuye la competencia para adoptar las medidas para la protección de su persona o de sus bienes a "las autoridades del Estado contratante en cuyo territorio se encuentran". Esta norma se aplica también a los niños cuya residencia habitual no pueda determinarse ${ }^{71}$.

\section{e) Competencia residual}

146. El art. 14 RB II ter establece una norma de competencia de carácter residual, aplicable solo cuando de los arts. 7 a 11 del Reglamento no se deduce la competencia de ningún órgano jurisdiccional de un Estado miembro ${ }^{72}$. En estos casos, la competencia se determinará, en cada Estado miembro, "con arreglo a las leyes de dicho Estado miembro"73.

147. La remisión a "las leyes de dicho Estado miembro" debe incluir no solo sus leyes nacionales, sino también los instrumentos internacionales que estén en vigor en dicho Estado ${ }^{74}$, cuyas normas deben ser aplicadas con preferencia a las normas internas ${ }^{75}$. Así, cuando el menor tenga su residencia habitual en un Estado parte del Convenio de La Haya de 1996 relativo a la Competencia (...) en materia de Responsabilidad Parental y de Medidas de Protección de los Niños, los órganos jurisdiccionales de un Estado miembro que no tengan competencia conforme al RB II ter, antes de aplicar sus normas internas, tendrán que comprobar si tienen competencia -o si esta corresponde a otro Estado parte-, conforme al Convenio de La Haya. Solo cuando el menor tenga su residencia habitual en un tercer Estado que no es parte del Convenio de La Haya, la competencia se determinará conforme al régimen legal interno de cada Estado miembro ${ }^{76}$.

148. Como ya se ha dicho, de acuerdo con las normas del RB II ter, los órganos jurisdiccionales de un Estado miembro solo tienen competencia para conocer en materia de responsabilidad parental respecto de un menor residente habitual fuera de la Unión Europea, si los padres -o cualquier otro titular de la responsabilidad parental- están de acuerdo (art. 10). En caso de que no lo estén, la posibilidad de iniciar un procedimiento ante un órgano jurisdiccional de un Estado miembro está sujeta a esta norma de competencia residual del art. 14 que conduce a aplicación de los convenios internacionales y, en su defecto, de la legislación nacional de cada uno de los Estados miembros.

149. Si atendemos al Estudio sobre la competencia residual (residual jurisdiction) realizado por el Prof. Nuyts en 2007 a propósito del RB II bis ${ }^{77}$, el examen de esas normas de competencia residual muestra que los ciudadanos de la Unión tienen un acceso desigual a la justicia, toda vez que las normas internas de los Estados miembros se basan en criterios diferentes y no siempre garantizan el acceso efectivo a los tribunales, a pesar de la estrecha relación de alguna de las partes con un Estado miembro.

${ }^{71}$ Cfr. Considerando 25 RB II ter.

${ }^{72} \mathrm{El}$ art. 14 RB II ter se corresponde con el art. 14 RB II bis, según la tabla de correspondencias que figura en el Anexo X.

73 Una interesante reflexión crítica sobre el enfoque erróneo de las normas europeas de competencia residual puede leerse en A. L. Calvo Caravaca / J. Carrascosa González, Derecho Internacional Privado, Vol. I, cit., p.129.

74 Considerando 29 RB II ter.

75 En España, la determinación de la competencia internacional de los órganos jurisdiccionales civiles se determina con arreglo a los arts. 22 a 22 nonies LOPJ. Estos artículos siguen la estructura de foros del Reglamento 1215/2012 (RB I bis), en el que claramente se inspiran. En materia de responsabilidad parental, véase, en particular, la letra d) del art. 22 quater LOPJ. No obstante, la aplicación real de estas normas resulta, en la práctica, muy marginal.

${ }^{76}$ En este mismo sentido, vid., P. Peiteado Mariscal, Procesos matrimoniales y resolución extrajudicial de la crisis del matrimonio y de la pareja, Colección 20 años LEC 2000, La Ley, Madrid, 2019, pág. 121.

77 Vid. A. NuYTs, "Study on residual jurisdiction..." cit., pp. 92-94. 
150. Así, en nueve Estados miembros la nacionalidad del menor es un punto de conexión comunitaria suficiente para atribuir a los tribunales la competencia judicial internacional. En otros cinco Estados miembros, la competencia puede fundarse en la nacionalidad de cualquiera de los padres, que con frecuencia coincide con la del menor ${ }^{78}$. En la práctica, eso significa que para los ciudadanos de catorce Estados miembros la competencia puede en general establecerse en la Unión Europea incluso cuando el menor (y sus padres) residen habitualmente en un tercer Estado.

151. Para los ciudadanos de los trece Estados miembros restantes solo habrá competencia residual en la Unión Europea si la situación presenta otro punto de conexión suficiente en virtud de la legislación nacional. Estos otros puntos de conexión están bastante diversificados y no tienen ninguna aplicación general. En algunos Estados miembros la materia de responsabilidad parental puede someterse al tribunal que se ocupa de cualquier procedimiento matrimonial (a menudo esta competencia existe incluso si no hay acuerdo entre las partes). Pero esto supone, por supuesto, que la competencia existe con respecto a los procedimientos matrimoniales y que tales procedimientos se inician en el Estado miembro pertinente. En otros Estados miembros, la competencia se establece con base en el domicilio o residencia habitual en el Estado del foro de una de las partes (unas veces el demandante, otras el demandado y otras cualquiera de ellos). Finalmente, en otros Estados miembros, la competencia con respecto a los menores que residen habitualmente en un tercer Estado puede establecerse en virtud de un forum necessitatis. En los Países Bajos hay una disposición específica que establece que los tribunales holandeses tienen competencia cuando el caso tiene conexión con el sistema legal holandés y el tribunal considera que está en una posición adecuada para evaluar el interés superior del menor. En otros países se aplica la norma general del forum necessitatis.

152. Así las cosas, pueden darse situaciones en las que ni un Estado miembro ni un tercer país sean competentes en materia de responsabilidad parental. Nótese, además, que a diferencia de otros instrumentos jurídicos de la Unión - $\mathrm{p}$, ej. los últimos Reglamentos en Derecho de familia ${ }^{79}$, el RB II ter no establece un forum necessitatis que permita a los órganos jurisdiccionales de un Estado miembro, con carácter excepcional, conocer de las cuestiones de responsabilidad parental si el proceso no pudiere incoarse o desarrollarse razonablemente o si resultare imposible en un tercer Estado con el que el asunto tuviese una conexión estrecha. Tradicionalmente se considera que esta competencia "de necesidad" se basa en el derecho a un juicio justo (o incluso viene impuesta por él mismo) en virtud del art. 6.1 $\mathrm{CEDH}^{80}$.

\section{Remisión de competencia a un órgano jurisdiccional de otro Estado miembro mejor situado para valorar el interés superior del menor (forum non conveniens)}

153. El art. 12 RB II ter, bajo la rúbrica "remisión de competencia a un órgano jurisdiccional de otro Estado miembro", establece una regla de competencia especial y excepcional respecto de la norma de competencia general del art. 7.1 RB II ter que designa a los órganos jurisdiccionales del Estado miembro de la residencia habitual del menor como los órganos competentes para conocer del fondo en los asuntos de responsabilidad parental. En virtud de esta regla especial, el Reglamento permite que el

\footnotetext{
${ }^{78}$ En España, en materia de responsabilidad parental, aparte de la residencia habitual del menor en España al tiempo de la interposición de la demanda, la nacionalidad española del demandante o su residencia habitual en España o, en todo caso, al menos desde seis meses antes de la presentación de la demanda son puntos de conexión suficiente para fundar la competencia internacional de los tribunales españoles (art. 22 quater LOPJ).

${ }^{79} \mathrm{Vid}$. Reglamento (UE) 2016/1103 del Consejo de 24 de junio de 2016 por el que se establece una cooperación reforzada en el ámbito de la competencia, la ley aplicable, el reconocimiento y la ejecución de resoluciones en materia de regímenes matrimoniales (art. 11), y Reglamento (UE) 2016/1104 del Consejo de 24 de junio de 2016 por el que se establece una cooperación reforzada en el ámbito de la competencia, la ley aplicable, el reconocimiento y la ejecución de resoluciones en materia de efectos patrimoniales de las uniones registradas (art. 11).

${ }^{80}$ Cfr. A. NuYTs, "Study on residual jurisdiction..." cit., p. 64.
} 
órgano jurisdiccional competente para conocer el fondo del asunto decline su competencia en favor de un órgano jurisdiccional de otro Estado miembro ${ }^{81}$.

154. Este precepto no hace sino acoger en el ámbito de aplicación propio del Reglamento la doctrina del denominado forum non conveniens. Se trata de una doctrina desconocida en los sistemas de civil law como el nuestro, pero frecuente en los sistemas de common law que permite al tribunal legalmente competente abstenerse de ejercer su competencia por reputarse menos adecuado o non conveniens en comparación con otro tribunal que, por tener mayor vinculación o puntos de conexión con el asunto planteado, reputa adecuado o conveniens ${ }^{82}$.

155. Aunque poco frecuente en el conjunto de las normas de competencia judicial civil en el ámbito de la Unión Europea, en el que, como regla, la determinación del tribunal competente se hace con arreglo a criterios prefijados de carácter legal, sin que ninguna disposición permita al tribunal competente declinar su competencia so pretexto de que existe un fuero de competencia más apropiado para conocer del litigio que aquel al que apunta la norma comunitaria, el art. 12 RB II ter no constituye en absoluto una disposición innovadora. Su predecesor, el art. 15 RB II bis, bajo la rúbrica "remisión a un órgano jurisdiccional mejor situado para conocer del asunto" ya contempla esta excepción, tomada a su vez de los arts. 8 y 9 del Convenio de La Haya de $1996^{83}$.

156. La naturaleza excepcional de esta norma de competencia respecto de la norma de competencia general del art. 7.1 RB II ter resulta incuestionable, toda vez que el propio art. $12 \mathrm{RB}$ II ter $-\mathrm{y}$ el considerando 26- establece expresamente que se aplicará "en circunstancias excepcionales". Además, el TJUE, siempre que ha tenido la oportunidad de pronunciarse sobre la interpretación de esta norma (art. 15 del RB II bis), aunque no siempre se le preguntara expresamente por ello, ha declarado que la remisión de competencia que permite esta norma debe producirse "únicamente con carácter excepcional" y, en consecuencia, "debe ser interpretada estrictamente" ${ }^{4}$. Así, en el Auto de 10 de julio de 2019, $E P$ y FO, C-530/18, el TJUE, respondiendo a una cuestión prejudicial en la que se le preguntaba expresamente por esta cuestión, dice así: "procede responder a la primera cuestión prejudicial que el artículo 15 del Reglamento $n .^{\circ}$ 2201/2003 debe interpretarse en el sentido de que establece una excepción a la regla de competencia general del artículo 8 de dicho Reglamento n. ${ }^{\circ}$ 2201/2003, según la cual la competencia de los órganos jurisdiccionales de los Estados miembros se determina en función del lugar de residencia habitual del menor en el momento de la presentación de la demanda". Por tanto, para poder

${ }^{81}$ Nótese que el art. 12 RB II ter solo permite que el órgano jurisdiccional competente decline su competencia en favor de un órgano jurisdiccional de otro Estado miembro, pero no en favor de un órgano jurisdiccional de un tercer país, lo que genera una considerable incertidumbre, especialmente cuando ese tercer Estado no es parte contratante del Convenio de La Haya de 1996, cuyo art. 8 contempla también la declinación de competencia en favor de un Estado contratante en mejor situación. Sobre la necesidad de abordar la posibilidad de declinar la competencia en favor de los órganos jurisdiccionales de un tercer Estado, vid., nuevamente, A. NuYTs, "Study on residual jurisdiction..." cit., pp. 141-145 y 154.

${ }^{82}$ Sobre el forum non conveniens, recomendamos la lectura del trabajo de B. SÁnchez LóPEz, "La responsabilidad parental y la aplicación del forum non conveniens de carácter reglado del artículo 15 del Reglamento (CE) $\mathrm{N}^{\circ}$ 2201/2003: la sentencia del 27 de octubre de 2016", en Cuadernos de Derecho Transnacional (Marzo 2018), Vol. 10, No 1, pp. 639-656. En este trabajo, a propósito del comentario de una sentencia del TJUE, la autora examina la función de esta doctrina en los sistemas de common law y los graves inconvenientes de su aplicación en el espacio UE. En la primera cita del trabajo, además, se cita abundante bibliografía sobre el forum non conveniens en coordenadas o en idioma español. También, de la misma autora, vid. "Cómo opera el procedimiento de forum non conveniens en la determinación de la competencia judicial europea en materia de responsabilidad parental”, en A. Ruda González / C. Jerez Delgado (dirs.), Estudios sobre Jurisprudencia Europea, Materiales del III Encuentro anual del Centro español del European Law Institute, Sepin, Madrid, 2019, pp. 643-655.

${ }^{83}$ Otro ejemplo de forum non conveniens en la Unión Europea lo proporciona el art. 6.a) del Reglamento (UE) $n^{0} 650 / 2012$, en materia de sucesiones mortis causa, en cuya virtud el tribunal con competencia para resolver la sucesión "podrá abstenerse de conocer, a instancia de una de las partes en el procedimiento, si considera que los tribunales del Estado miembro cuya ley fue elegida están en mejor situación para pronunciarse sobre la sucesión, habida cuenta de las circunstancias prácticas de esta, tales como la residencia habitual de las partes y la ubicación de los bienes".

${ }^{84}$ Sobre la naturaleza excepcional de la remisión de competencia y su interpretación restrictiva, vid. SSTJUE de 27 de octubre de 2016 (asunto Child and Family), y de 4 de octubre de 2018 (asunto IQ y JP). 
remitir la competencia a un órgano jurisdiccional de otro Estado miembro, será necesario que el órgano jurisdiccional competente para conocer el fondo del asunto desvirtúe la fuerte presunción a favor del mantenimiento de su propia competencia.

157. El art. 12 RB II ter, al igual que su predecesor, ha adoptado una fórmula reglada de forum non conveniens en cuanto a la predeterminación de los requisitos que han de concurrir para que pueda operar esta norma excepcional y al abanico de órganos jurisdiccionales que pueden ser considerados conveniens. Los requisitos que exige el art. $12 \mathrm{RB}$ II ter para que el órgano jurisdiccional competente decline su competencia en favor del órgano jurisdiccional de otro Estado miembro son : $1^{\circ}$ ) que el menor tenga un "vínculo estrecho" con ese otro Estado miembro; $2^{\circ}$ ) que el órgano jurisdiccional de ese otro Estado miembro "esté mejor situado" para conocer del asunto -o de una parte específica- que él; y $3^{\circ}$ ) que la remisión de competencia responda al "interés superior del menor". Solo entonces puede el órgano jurisdiccional competente suspender el procedimiento y dar comienzo al incidente dirigido a declinar su competencia en favor de un órgano jurisdiccional de otro Estado miembro.

158. Hay que señalar, antes de pasar a examinar estos tres requisitos, que el órgano jurisdiccional del otro Estado miembro con el que el menor tiene un vínculo estrecho y que está mejor situado para conocer del asunto, no puede ser el órgano jurisdiccional normalmente competente para conocer del fondo del asunto sobre la base de los arts. 7 o 10 RB II ter. En este sentido, el TJUE, en sentencia de 4 de octubre de 2018, IQ y JP, C-478/17, señaló que el art. 15 RB II bis -ahora, art. 12 RB II ter"debe interpretarse en el sentido de que no es aplicable en una situación (...) en la que los dos órganos jurisdiccionales a los que se ha sometido el asunto son competentes para conocer del fondo del mismo en virtud, respectivamente, de los artículos 12 [prórroga de competencia] y 8 [competencia general]de dicho Reglamento" $"$.

\section{A) Vinculación estrecha del menor con el órgano jurisdiccional del otro Estado miembro}

159. En primer lugar, es requisito necesario para que el órgano jurisdiccional competente pueda declinar su competencia en favor de un órgano jurisdiccional de otro Estado miembro que el menor tenga un "vínculo estrecho" con ese Estado. Así lo pide el aptdo. 1 del art. 12 RB II ter, y el aptdo. 4 de este mismo precepto establece en qué ha de consistir este vínculo estrecho ${ }^{86}$. Así, para el legislador europeo este vínculo estrecho entre el menor y los órganos jurisdiccionales de un Estado miembro se da en las

\footnotetext{
${ }^{85}$ Para el TJUE, interpretar el art. 15 en el sentido de que autoriza la remisión de un asunto a un órgano jurisdiccional de un Estado miembro competente para conocer del fondo del asunto "privaría de sentido al artículo 19, apartado 2, (...), que pretende resolver, en materia de responsabilidad parental, las situaciones en las que son competentes órganos jurisdiccionales situados en distintos Estados miembros. En efecto, esta disposición establece que, cuando se presentaren demandas relativas a la responsabilidad parental sobre un menor que tengan el mismo objeto y la misma causa ante órganos jurisdiccionales de distintos Estados miembros, el órgano jurisdiccional ante el que se hubiere presentado la segunda demanda suspenderá de oficio el procedimiento en tanto no se establezca la competencia del órgano jurisdiccional ante el que se interpuso la primera". Nótese, no obstante, que con el RB II ter la competencia fundada en el art. 10, esto es, la competencia convenida libremente o aceptada expresamente por las partes, pasa a ser una competencia exclusiva, de ahí que los apartados 4 y 5 del art. 20 RB II ter, relativo a la litispendencia, señale lo siguiente: "cuando se haya iniciado un procedimiento ante un órgano jurisdiccional de un Estado miembro que tenga competencia exclusiva como consecuencia de la aceptación de competencia a que se hace referencia en el art. 10, los órganos jurisdiccionales de otros Estados miembros suspenderán el procedimiento hasta tanto el órgano jurisdiccional ante el que se haya interpuesto el procedimiento en virtud del acuerdo o aceptación declare que no tiene competencia con arreglo al acuerdo o aceptación. En los casos y en la medida en que el órgano jurisdiccional haya establecido su competencia exclusiva de conformidad con una aceptación de competencia a que se hace referencia en el artículo 10, cualquier órgano jurisdiccional de los demás Estados miembros deberán inhibirse en favor de aquél". Un comentario crítico a los argumentos de esta sentencia puede leerse en S. Álvarez GonZÁlez, "De nuevo sobre la interpretación y alcance del artículo 15 del Reglamento Bruselas II bis. (Una alternativa efímera a la STJ de 4 de octubre de 2018), en La Ley Unión Europea $\mathrm{n}^{\circ}$ 66, enero 2019.

${ }^{86}$ El art. 15 RB II bis habla de "vinculación especial”, en vez de "vínculo estrecho", pero el contenido de ambas expresiones es exactamente el mismo.
} 
siguientes situaciones: a) dicho Estado miembro se ha convertido en el de residencia habitual del menor después de la presentación de la demanda ${ }^{87}$; b) el menor ha residido de manera habitual en dicho Estado miembro (pero ya no lo hace); c) el menor es nacional de dicho Estado; d) dicho Estado miembro es el de residencia habitual de uno de los titulares de la responsabilidad parental; o e) el asunto se refiere a las medidas de protección del menor ligadas a la administración, conservación o disposición de los bienes de este que se encuentran en el territorio de dicho Estado miembro.

160. Como ha señalado el TJUE, la enumeración de los supuestos en lo que existe un vínculo estrecho del menor con otro Estado miembro que recoge el aptdo. 4 del art. 12 RB II ter, a diferencia de lo previsto en el art. 10 para la elección de foro ${ }^{88}$, no es meramente ejemplificativa y abierta, sino tasada o exhaustiva. Se trata de "elementos enumerados, con carácter exhaustivo (...). Por consiguiente, de entrada se excluyen del mecanismo de remisión los asuntos en los que no se aprecien dichos elementos" ${ }^{\prime 2}$.

161. Nótese que los cinco elementos que menciona el art. 12.4 RB II ter testimonian, si no expresamente, al menos en esencia, la existencia de una proximidad entre el menor afectado y un Estado miembro diferente del Estado miembro del órgano jurisdiccional competente para conocer del asunto con arreglo al art. 7.1 RB II ter. Los dos primeros elementos se refieren a la residencia del menor afectado en el otro Estado miembro, adquirida bien anteriormente, bien con posterioridad a la presentación de la demanda ante el órgano competente. El tercer elemento hace referencia a la nacionalidad del menor. El cuarto crea la proximidad del menor con el otro Estado miembro a través de la residencia habitual de uno de los titulares de la responsabilidad parental en dicho Estado y, el quinto se refiere a la presencia de los bienes del menor en este otro Estado miembro.

162. Como ha dicho el TJUE, puesto que es común a todos los elementos enumerados la presencia de un criterio de proximidad entre el menor y el Estado miembro diferente al que apunta la norma de competencia general, el órgano jurisdiccional competente que pretenda remitir su competencia a los tribunales de otro Estado miembro "debe comparar la importancia y la intensidad del vínculo de proximidad «general» que une al menor afectado, con arreglo al artículo 8, apartado 1, de este Reglamento, con la importancia y la intensidad del vínculo de proximidad «especial» demostrado por uno o varios de los elementos enunciados en el artículo 15, apartado 3, de dicho Reglamento y que exista, en el caso concreto, entre el menor y otros Estados miembros". No obstante, "la existencia de una «vinculación especial» (...) en sí misma no prejuzga necesariamente la cuestión de si un órgano jurisdiccional de otro Estado miembro está «mejor situado para conocer del asunto» (...), así como tampoco (...) la relativa a si la remisión del asunto a este último órgano jurisdiccional responde al interés superior del menor. Por consiguiente, también corresponde al órgano jurisdiccional competente determinar, en segundo lugar, si en el otro Estado miembro con el que el menor tenga una vinculación especial, existe un órgano mejor situado para conocer del asunto" $"$.

${ }^{87}$ Como ya se adelantó, como regla, los cambios de residencia habitual del menor posteriores a la presentación de la demanda no alteran la competencia ya determinada del tribunal, por aplicación de la regla de la perpetuatio iurisdictionis. No obstante, en virtud del art. 12 RB II ter, si el menor cambia su residencia habitual a otro Estado miembro después de presentada la demanda, cabe la posibilidad de que el tribunal que conoce del asunto considere que los tribunales del Estado miembro de la nueva residencia habitual del menor están mejor situados para valorar el interés superior del menor y decline su competencia en favor de ellos.

${ }^{88}$ Recuérdese que el art. 10 RB II ter también condiciona la elección de órgano jurisdiccional a la vinculación estrecha del menor con el Estado elegido y también enumera los supuestos en que se entiende que existe tal vínculo, pero en ese caso se trata de una enumeración que reviste un carácter meramente indicativo, como se deduce del empleo de la expresión "en especial", tal y como ha declarado el TJUE en varias ocasiones (vid. STJUE de 27 de noviembre de 2007, $C$, C-435/06, STJUE de 26 de abril de 2012, Health Service Executive, C-92/12 PPU y STJUE de 21 de octubre de 2015, Gogova, C-215/15).

${ }^{89}$ STJUE de 27 de octubre de 2016, Child and Family y J.D., C-428/15. Vid., también, STJUE de 4 de octubre de 2018, IQ y JP, C-478/17 y ATJUE de 10 de julio de 2019, EP y FO, C-530/18.

${ }^{90}$ STJUE de 27 de octubre de 2016 (asunto Child and Family y J.D.). 


\section{B) Mejor situación del órgano jurisdiccional del otro Estado miembro para valorar el interés su- perior del menor}

163. El requisito de que el menor tenga un vínculo estrecho con un Estado miembro es requisito necesario pero no suficiente para que el órgano jurisdiccional competente pueda declinar su competencia y remitir el asunto al órgano jurisdiccional del otro Estado miembro. Es necesario también que el órgano jurisdiccional del otro Estado miembro "esté mejor situado" para valorar el interés superior del menor. Por tanto, el órgano jurisdiccional competente tendrá que determinar si el órgano jurisdiccional del otro Estado miembro con el que el menor tiene un vínculo estrecho está mejor situado que él para conocer del asunto. Si el órgano jurisdiccional competente llega a la conclusión de que los vínculos que unen al menor afectado al Estado miembro de su residencia habitual son más fuertes que los que le unen a otro Estado miembro, ello bastará para excluir la aplicación del art. 12 RB II ter.

164. En la STJUE de 27 de octubre de 2016 (asunto Child and Family y J.D.) encontramos, de un lado, los elementos concretos que deben considerarse para determinar qué órgano jurisdiccional está mejor situado para valorar el interés superior del menor y, de otro lado, los elementos que no deben valorarse.

"A tal efecto, el órgano jurisdiccional competente debe determinar si, con respecto a la hipótesis de que mantiene su competencia, la remisión del asunto a ese otro órgano jurisdiccional puede aportar un valor añadido real y concreto para la adopción de una decisión sobre el menor. En este contexto, puede tener en cuenta, entre otros, las normas procesales del otro Estado miembro, como las aplicables a la obtención de las pruebas necesarias para resolver el asunto".

En cambio, "el órgano jurisdiccional competente no debería tener en cuenta el derecho material del otro Estado miembro eventualmente aplicable por el órgano jurisdiccional de este último, en el caso de que le fuera remitido el asunto. En efecto, la consideración de tal aspecto sería contraria a los principios de confianza mutua entre Estados miembros y de reconocimiento mutuo de las resoluciones judiciales en las que se funda el Reglamento n. ${ }^{\circ} 2201 / 2003{ }^{\prime \prime 91}$.

165. Según el TJUE, por tanto, para determinar si la remisión del asunto puede aportar un valor añadido real y concreto, queda excluida la posibilidad de que el órgano jurisdiccional competente pueda tomar en consideración el Derecho sustantivo del otro Estado miembro con el que el menor presenta un vínculo especial, pero sí podrá considerar su Derecho procesal. No obstante, el propio TJUE en una resolución posterior, ATJUE de 10 de julio de 2019, EP y FO, C-530/18, ha declarado que "el órgano jurisdiccional competente puede tener en cuenta normas de procedimiento aplicables con arreglo a la legislación de otro Estado miembro si estas tienen una incidencia concreta en la capacidad del órgano jurisdiccional de este último Estado para conocer mejor del asunto, en particular al facilitar la obtención de pruebas y de testimonios, aportando con ello un valor añadido para resolver el asunto en interés superior del menor. En cambio, no puede considerarse de manera general y abstracta que normas jurídicas de otro Estado miembro como las mencionadas por una de las partes en el litigio principal, a saber, las normas relativas al examen del asunto a puerta cerrada y por jueces especializados, constituyan un elemento que el juez competente deba tener en cuenta al evaluar la existencia de un órgano jurisdiccional mejor situado para conocer del asunto".

\section{C) La remisión de competencia ha de responder al interés superior del menor}

166. Como tercer requisito, el art. 12.1 RB II ter exige que la remisión de competencia responda al "interés superior del menor", que, como es sabido, constituye el valor que preside todas las normas del Reglamento en materia de responsabilidad parental.

\footnotetext{
${ }^{91}$ Vid. S. Álvarez GonzÁlez, "Responsabilidad parental, transferencia de la competencia a los órganos jurisdiccionales de otro Estado miembro e interés superior del menor, STJUE 27 de octubre de 2016, C-428/15: D”, en La Ley Unión Europea, ${ }^{\circ}$ 43, diciembre 2016.
} 
167. En principio, puede pensarse que el cumplimiento de los dos primeros requisitos lleva consigo forzosamente la concurrencia del tercero, esto es, que la remisión de competencia a un órgano jurisdiccional de un Estado miembro con el que el menor tiene un vínculo estrecho en el sentido del aptdo. 4 del art. 12 RB II ter y que está mejor situado para conocer del asunto sirve necesariamente a la finalidad del interés superior del menor. Sin embargo, el TJUE en la sentencia anterior (asunto Child and Family y J.D) atribuye autonomía a este tercer requisito y exige que "el órgano jurisdiccional se cerciore, a la vista de las circunstancias concretas del asunto, de que la remisión que valora efectuar al órgano jurisdiccional de otro Estado miembro no pueda incidir negativamente sobre la situación del menor afectado. A tal fin, el órgano jurisdiccional debe valorar la posible incidencia negativa de tal remisión sobre las relaciones afectivas, familiares y sociales o sobre la situación económica del menor de que se trate". Y recuerda que no es irrelevante que este precepto permita remitir solo una parte específica del asunto si las circunstancias así lo aconsejan, por ejemplo, cuando el vínculo de proximidad con otro Estado miembro no concierne directamente al propio menor sino a uno de los titulares de la responsabilidad parental que tiene en dicho Estado su residencia habitual ${ }^{92}$.

\section{D) Procedimiento}

168. Dándose los tres requisitos anteriores, el órgano jurisdiccional inicialmente competente, de oficio o a instancia de parte ${ }^{93}$, aun cuando no tiene la obligación de hacerlo ${ }^{94}$, puede suspender el conocimiento del procedimiento o de una parte específica del mismo y dar comienzo al incidente dirigido a declinar su competencia, bien fijando un plazo a las partes para que informen al órgano jurisdiccional del otro Estado miembro de las causas pendientes y de la posibilidad de remitir la competencia y presentar una solicitud ante dichos órganos, o bien solicitando al órgano jurisdiccional del otro Estado miembro que ejerza su competencia (art. 12.1 RB II ter) ${ }^{95}$.

169. En ambos supuestos todavía es necesario que el órgano jurisdiccional del otro Estado miembro considere que, por las circunstancias específicas del asunto, la remisión responde al interés superior del menor y, en consecuencia, se declare competente en el plazo de seis semanas. El órgano señalado como mejor situado debe informar sin demora al órgano jurisdiccional inicialmente competente, ya sea directamente conforme al art. 86 o por conducto de las autoridades centrales designadas en virtud del art. 76. Si acepta la competencia, el órgano ante el que se presentó la solicitud en primer lugar deberá inhibirse (art. 12.2 RB II ter). En cambio, si no recibe la aceptación de la competencia del órgano jurisdiccional del otro Estado miembro en las siete semanas posteriores a la expiración del plazo fijado a las partes para presentar la solicitud, o dicho órgano jurisdiccional haya recibido la solicitud, seguirá ejerciendo su competencia (art. 12. 3 RB II ter). De esta forma, el Reglamento consigue coordinar la abstención del primer tribunal con la competencia que tiene que afirmar el segundo antes de que la competencia le sea transferida para que así no exista un vacío» en la competencia del tribunal.

170. Nótese que el órgano jurisdiccional reputado conveniens puede aceptar la remisión de competencia o no hacerlo, pero en caso de aceptarla no puede, a su vez, remitir el asunto a un tercer órgano

\footnotetext{
${ }_{92}$ En el asunto que resuelve esta sentencia, el TJUE insiste en que para valorar el riesgo de que la eventual remisión del asunto incida negativamente en la situación del menor (en este caso concreto, en su derecho de circulación), solo deben tenerse en cuenta lo elementos que puedan repercutir negativamente en la situación del menor, pero no las consideraciones relativas a otras personas a las que pueda afectar el asunto (a la madre, en este caso), a menos que también resulten pertinentes para evaluar el riesgo del menor.

${ }^{93} \mathrm{El}$ actual art. $15 \mathrm{RB}$ II bis también prevé que la remisión pueda efectuarse de oficio o a instancia de parte, pero en este segundo caso se exige el consentimiento de al menos una de la partes, exigencia que ya no aparece en el art. 12 RB II ter.

${ }_{94}$ Vid. Considerando 26 RB II ter y ATJUE de 10 de julio de 2019, EP y FO, C-530/18, apartados. 30 y 36.

${ }^{95}$ De conformidad con el considerando 26 RB II ter, el órgano jurisdiccional que tiene la competencia debe hacer la correspondiente solicitud al órgano del otro Estado miembro únicamente cuando su resolución previa de suspender el procedimiento y hacer la solicitud de transferencia de competencia sea firme, en caso de que dicha resolución sea susceptible de recurso en virtud de la legislación nacional.
} 
jurisdiccional. El RB II ter, a diferencia del RB II bis (considerando 13), no veda expresamente esta posibilidad, pero se deduce del carácter excepcional de esta norma de competencia.

\section{E) Prohibición de remisión en caso de competencia exclusiva}

171. Por último, el aptdo. 5 del art 12 RB II ter prohíbe la remisión de la competencia "en los casos en que se haya determinado la competencia exclusiva del órgano jurisdiccional de conformidad con el artículo 10". Recuérdese que, conforme al aptdo. 4 del art. 10 RB II ter, la competencia convenida libremente o aceptada expresamente por las partes durante el procedimiento, siempre que el órgano jurisdiccional se haya asegurado de que todas las partes han sido informadas de su derecho a no aceptar la competencia, se ejerce con carácter exclusivo. En estos casos, por tanto, el tribunal competente elegido por las partes no podrá remitir la competencia a los órganos jurisdiccionales de otro Estado miembro con el que el menor tenga un vínculo estrecho en el sentido del art. 12.4 RB II ter, aunque considere que está mejor situado que él para valorar el interés superior del menor ${ }^{96}$.

\section{Transferencia de competencia solicitada por un órgano jurisdiccional de un Estado miembro que no tenga competencia}

172. El art. 13 RB II ter prevé la posibilidad de que el órgano jurisdiccional de residencia habitual del menor transfiera la competencia a un órgano jurisdiccional de otro Estado miembro, que no tiene competencia en virtud del Reglamento, a petición de este segundo órgano jurisdiccional. Los arts. 12 y 13 RB II ter son las dos caras de una misma moneda: el primero, como hemos visto, regula la remisión de competencia a un órgano jurisdiccional de otro Estado miembro, de oficio o a instancia de parte; el segundo contempla la transferencia de competencia a petición del órgano jurisdiccional del otro Estado miembro.

173. Aunque en el RB II bis no encontramos un artículo como este dedicado en exclusiva a regular la transferencia de competencia a petición de un órgano jurisdiccional de un Estado miembro que no tenga competencia, no se trata de una norma novedosa del RB II ter, toda vez que esta posibilidad está contemplada en el art. 15 RB II bis dedicado a la remisión de la competencia, pues, según dice este precepto, la remisión puede producirse de oficio, a instancia de parte o a petición del órgano jurisdiccional de otro Estado miembro con el que el menor tenga una vinculación especial. En este caso, para que la remisión pueda efectuarse, al igual que para hacerlo de oficio, se exige el consentimiento de alguna de las partes. Lo único que hace el RB II ter es regular la transferencia de competencia de forma autónoma, ganándose con ello en claridad, además de suprimir la necesidad del consentimiento de una de las partes.

174. Para que esta transferencia de competencia pueda tener lugar, el art. $13.1 \mathrm{RB}$ II ter, al igual que el art. 12.1 RB II ter, exige que el menor afectado tenga un "vínculo estrecho" con el Estado miembro que solicita la transferencia, de conformidad con lo previsto en el aptdo. 4 del art. 12 RB II ter, y que el órgano jurisdiccional solicitante considere que, en el caso particular de que se trate, puede valorar mejor el "interés superior del menor".

175. Presentada la solicitud de transferencia, el órgano jurisdiccional requerido dispone de seis semanas desde su recepción para decidir si acepta o no. Si considera que debido a las circunstancias específicas del caso, dicha transferencia responde al interés superior del menor puede aceptar transferir su competencia, informando sin demora al órgano jurisdiccional solicitante. Si dentro de dicho plazo el

\footnotetext{
${ }^{96}$ Esta prohibición constituye una novedad del RB II ter, no contemplada en el RB II bis. En la actualidad, bajo la videncia del RB II bis, la remisión puede realizarla el órgano jurisdiccional que sea competente, bien en virtud de la regla general establecida en el art. 8.1 o en virtud de la norma de prórroga de la competencia del art. 12. Vid. STJUE de 4 de octubre de 2018 , $I Q y J P, \mathrm{C}-478 / 17$.
} 
órgano requerido no acepta expresamente la transferencia de competencia solicitada, el órgano peticionario no podrá ejercerla.

\section{Competencia para adoptar medidas provisionales, incluidas las cautelares, en casos de urgencia}

176. Sin duda alguna, los órganos jurisdiccionales competentes para conocer de un determinado litigio en materia de responsabilidad parental en virtud de alguna de las normas de competencia del RB II ter tienen aptitud para resolver el fondo de la cuestión, pero también están facultados, en virtud de la competencia que poseen, para adoptar las medidas cautelares que resulten procedentes en relación con la persona del menor o sus bienes. No obstante, el art. 15 RB II ter permite, en caso de urgencia, la solicitud y adopción de "medidas provisionales, incluidas las cautelares" ${ }^{97}$, en relación con la persona o con los bienes de un menor, a los órganos jurisdiccionales del Estado miembro en el que esté presente el menor o en el que se encuentren sus bienes, a pesar de que, con arreglo al propio Reglamento, estos no sean competentes para conocer del fondo del litigio.

177. La atribución de competencia para adoptar medidas provisionales a órganos jurisdiccionales no competentes para conocer del fondo del asunto no supone una novedad del RB II ter. El actual art. 20 RB II bis, incluido en las "Disposiciones comunes" de la Sección 3 del Capítulo II, dedicado a la "Competencia", ya contempla esta atribución. Así, según el apartado 1 del art. 20, "en caso de urgencia, las disposiciones del presente Reglamento no impedirán que los órganos jurisdiccionales de un Estado miembro adopten medidas provisionales o cautelares previstas en su propia legislación en relación con personas o bienes presentes en dicho Estado miembro, aun cuando, en virtud del presente Reglamento, un órgano jurisdiccional de otro Estado miembro fuere competente para conocer sobre el fondo". No obstante, debe advertirse que el RB II ter ha sacado esta disposición de las "Disposiciones comunes" a la materia matrimonial y a la responsabilidad parental, y se la ha llevado a la Sección 2 del Capítulo II, dedicada exclusivamente a las normas de competencia en materia de responsabilidad parental. Este cambio de ubicación de la norma, junto con la nueva redacción dada por el legislador europeo al art. 15.1 RB II ter, lleva consigo un cambio importante que no puede pasar desapercibido.

178. En efecto, con el nuevo art. 15 RB II ter, la adopción de medidas provisionales por un órgano jurisdiccional de un Estado miembro no competente para conocer del fondo solo está justificada con finalidades precautorias de la persona o bienes de un menor. Por tanto, en aquellos casos en que no existan menores o la finalidad de las medidas provisionales que se soliciten no sea la protección de la persona o de los bienes de un menor, solo será posible acudir en solicitud de medidas cautelares a los órganos jurisdiccionales del Estado miembro competente para conocer del fondo del asunto.

179. Los requisitos acumulativos que impone el art. 15.1 RB II ter para que los órganos jurisdiccionales de un Estado miembro que no sean competentes para conocer del fondo del asunto puedan adoptar medidas provisionales son los siguientes:

180. $1^{\circ}$ ) Las medidas provisionales deben ser urgentes. El apartado 1 del art. 15 RB II ter comienza así: "En caso de urgencia, (...)". Se exige así a quien pida las medidas cautelares que alegue y acredite razones de urgencia que justifiquen la solicitud de medidas provisionales ante un órgano juris-

${ }^{97}$ Sobre el significado de la expresión "medidas provisionales, incluidas las cautelares", me remito al trabajo de F. GASCÓN Inchausti, "Capítulo X. Medidas cautelares (art. 31 RB)", en A. De la Oliva Santos / F. Gascón Inchausti (dirs.), Competencia judicial internacional, reconocimiento y ejecución de resoluciones judiciales en la Unión Europea, cit., pp. 312-322. Aunque este trabajo tiene por objeto el estudio de las medidas provisionales y cautelares en el Reglamento 44/2001, las consideraciones del autor acerca de esta noción son perfectamente trasladables al ámbito que ahora nos ocupa, toda vez que el concepto de medidas provisionales que emana de la jurisprudencia del TJUE es un concepto propiamente comunitario y autónomo del de los ordenamientos jurídicos internos. Del mismo autor, vid., también, Medidas cautelares de proceso civil extranjero (Art. 24 del Convenio de Bruselas), Comares, Granada, 1998, pp.31-63. 
diccional de un Estado miembro que no es el competente para conocer del fondo del litigio. El concepto de "urgencia" de esta disposición -rectius, del art. 20 RB II bis-, ha sido interpretado por el TJUE en el sentido de que "se refiere a la vez a la situación en la que se encuentra el menor y a la imposibilidad práctica de presentar la demanda sobre la responsabilidad parental ante el órgano jurisdiccional competente para conocer el fondo" 98 . Esta interpretación del TJUE sobre el requisito de "urgencia" implica que la medida provisional solicitada no solo ha de ser urgente, en el sentido de necesaria, en atención a la situación en que se encuentra el menor, sino que dicha urgencia tiene que consistir también -"a la vez", según el TJUE- en que el tiempo necesario para preparar y presentar la demanda ante los órganos jurisdiccionales del Estado miembro competente para conocer del fondo puede hacer ineficaz la medida cautelar que entonces se adopte. Y esto, a su vez, significa que, necesariamente, ha de tratarse de una solicitud de medidas cautelares ante causam, esto es, previa a la presentación de la demanda antes los órganos jurisdiccionales del Estado miembro competente para conocer del fondo del litigio. No cabe, pues, la posibilidad de que se pidan medidas provisionales ante un órgano jurisdiccional de un Estado miembro en el que está presente el menor o allí se encuentran sus bienes, una vez que ya se está tramitando el proceso principal ante los órganos jurisdicciones del Estado miembro competente.

181. $2^{\circ}$ ) Un órgano jurisdiccional de otro Estado miembro ha de ser competente para conocer sobre el fondo en virtud del RB II ter: la competencia para conocer del fondo debe corresponder necesariamente a un Estado miembro de la Unión Europea, ya sea por aplicación de la norma de competencia general del art. 7.1, ya sea por cualquiera de las otras normas de competencia del Reglamento (por ejemplo, un acuerdo de elección de foro en virtud del art. 10).

182. $3^{\circ}$ ) Las medidas provisionales deben adoptarse en relación con un menor que esté presente en dicho Estado o en el que se encuentren sus bienes. El art. 15 RB II ter no permite acudir en solicitud de una medida cautelar a los órganos jurisdiccionales de cualquier Estado miembro, sino que identifica los fueros internacionales a los que puede acudirse. Según este precepto, la presencia del menor o de sus bienes en un Estado miembro es el punto de conexión comunitaria suficiente para atribuir competencia en materia cautelar a órganos jurisdiccionales no competentes en cuanto al fondo. De ordinario, las medidas provisionales son aplicables a menores que teniendo su residencia habitual en un Estado miembro residen con carácter temporal u ocasional en otro Estado miembro y se encuentran en una situación que puede perjudicar gravemente a su bienestar, incluida su salud, o a su desarrollo, por lo que está justificada la adopción inmediata de medidas de protección.

183. $4^{\circ}$ ) Las medidas provisionales solicitadas deben estar previstas en la legislación nacional de dicho Estado miembro. El Reglamento no contiene disposición material alguna relativa a la clase de medidas urgentes que han de aplicarse, sino que es competencia del legislador nacional establecer las medidas que las autoridades nacionales han de adoptar para preservar el interés superior del menor y fijar las modalidades procesales para su ejecución. Al tener lugar la adopción de tales medidas sobre la base de las disposiciones del Derecho nacional, su carácter vinculante ha de resultar de la legislación nacional de que se trate ${ }^{99}$.

184. Dándose conjuntamente todos estos requisitos, el art. 15.1 RB II ter faculta a un órgano jurisdiccional que no es competente para conocer del fondo para adoptar, excepcionalmente, medidas provisionales. En la medida en que constituye una excepción al sistema de competencia previsto por el Reglamento, esta disposición debe interpretarse de modo estricto ${ }^{100}$.

${ }^{98}$ STJUE de 23 de diciembre de 2009, Deticěk, C-403/09 PPU. En este mismo sentido, vid., STJUE de 15 de julio de 2010, Purrucker, C-256/09.

${ }^{99}$ Cfr. STJUE de 2 de abril de 2009, A, C-523/07.

${ }^{100}$ Cfr. STJUE de 23 de diciembre de 2009, Deticěk, C-403/09 PPU. 
185. De acuerdo con el apartado 2 del art. 15 RB II ter, siempre que la protección del interés superior del menor lo exija, el órgano jurisdiccional que haya adoptado la medida provisional debe informar sin demora al órgano jurisdiccional o a la autoridad competente del Estado miembro de la residencia habitual del menor o, en su caso, a cualquier órgano jurisdiccional de un Estado miembro competente para conocer del fondo del asunto en virtud del Reglamento, ya sea directamente o por conducto de las autoridades centrales.

186. Con esta disposición, el legislador europeo incorpora al RB II ter la doctrina del TJUE sobre la necesidad de informar al órgano jurisdiccional competente para conocer del fondo del litigio tras la adopción de la medida cautelar. Preguntado sobre la necesidad o no de que tras la adopción de la medida cautelar se trasladen los autos al órgano jurisdiccional competente del otro Estado miembro -cuestión sobre la que el actual art. 20 RB II bis guarda silencio-, el TJUE en sentencia de 2 de abril de 2009, $A$, C-523/07, señaló que "tras la adopción de la medida cautelar, el órgano jurisdiccional nacional no está obligado a remitir el asunto al órgano jurisdiccional competente de otro Estado miembro. Sin embargo, siempre que la protección del interés superior del menor lo exija, el órgano jurisdiccional nacional que haya adoptado las medidas provisionales o cautelares, debe informar de ellas al órgano jurisdiccional competente de otro Estado miembro directamente o por conducto de la autoridad central designada (...)".

187. La argumentación del TJUE en defensa de este deber de información es incontestable, a saber: “(...) las medidas provisionales o cautelares dejarán de aplicarse cuando el órgano jurisdiccional del Estado miembro competente para conocer del fondo haya adoptado las medidas que considere apropiadas. Habida cuenta de que las medidas provisionales o cautelares tienen carácter transitorio, las circunstancias vinculadas a la evolución física, psicológica e intelectual del menor pueden hacer necesaria la intervención temprana del órgano jurisdiccional competente para que se adopten las medidas definitivas. La necesidad y la urgencia de adoptar medidas definitivas deben apreciarse en función de la situación del menor, la evolución previsible de esta y la eficacia de las medidas provisionales o cautelares adoptadas. En estas circunstancias, la protección del interés superior del menor puede exigir que el órgano jurisdiccional nacional que haya adoptado las medidas provisionales o cautelares informe de ellas al órgano jurisdiccional competente de otro Estado miembro".

188. Por último, el apartado 3 del art. 15 RB II ter, al igual que el actual art. 20.2 RB II bis, establece que las medidas provisionales adoptadas por un órgano jurisdiccional de un Estado miembro incompetente para conocer del fondo del asunto, "dejarán de ser aplicables tan pronto como el órgano jurisdiccional del Estado miembro competente para conocer del fondo haya adoptado las medidas que considere apropiadas". Esta norma no hace más -ni menos- que recoger uno de los elementos caracterizadores de las medidas cautelares, su provisionalidad en el tiempo. Previene, además, todo riesgo de contradicción entre una resolución de adopción de medidas provisionales y una resolución adoptada por el órgano jurisdiccional competente para conocer del fondo del asunto, puesto que la primera dejará de aplicarse cuando el órgano jurisdiccional competente para conocer del fondo haya adoptado las medidas que considere adecuadas ${ }^{101}$. La novedad de esta disposición está también en el deber que se impone al órgano jurisdiccional de informar de su decisión al órgano que adoptó las medidas cautelares, directamente o a través de las autoridades centrales designadas.

189. Por último, en la materia que nos ocupa merece destacarse la STJUE de 23 de diciembre de 2009, Deticěk, C-403/09 PPU, en la que el Tribunal de Justicia sienta las directrices sobre cómo aplicar las medidas cautelares en los casos de sustracción de menores. Esta sentencia resuelve una cuestión prejudicial presentada por el Tribunal de apelación de Maribor (Eslovenia), en el marco de un litigio entre la Sra. Deticěk y el Sr. Sgueglia, en relación con la custodia de su hija. En este caso, la madre había trasladado ilícitamente a la menor de Italia a Eslovenia el mismo día en que un tribunal italiano, competente para conocer sobre el fondo en materia de responsabilidad parental, había dictado una resolución concediendo

${ }^{101}$ Cfr. STJUE de 9 de noviembre de 2010, Purrucker, C-296/10. 
provisionalmente al padre la custodia exclusiva de la menor y ordenando el alojamiento provisional de la menor en una casa de acogida en Roma; resolución que fue declarada ejecutiva en Eslovenia. Con posterioridad, la la Sra. Deticěk presentó ante un tribunal esloveno una demanda de medidas provisionales y cautelares solicitando que se le concediera la custodia de la menor. El tribunal esloveno estimó la demanda y le concedió provisionalmente la custodia de la hija. Fundó su competencia en el art. 20 RB II bis, apoyándose en el cambio de circunstancias producido desde que el tribunal italiano adoptó la medida provisional que atribuía la custodia exclusiva de la menor a su padre, consistente en que la menor se había integrado en su entorno social en Eslovenia y que su regreso a Italia y su acogimiento forzoso en una casa de acogida serían contrarios a su bienestar, puesto que le provocarían un trauma físico y psíquico irreversible. En circunstancias como las del litigio principal, el TJUE realizó las siguientes declaraciones:

190. $1^{\text {a }}$ ) Las circunstancias invocadas no permiten fundamentar la existencia de urgencia en el sentido del art. 20 RB II bis. El reconocimiento de una situación de urgencia en un caso como este sería contrario al principio de reconocimiento mutuo de las resoluciones judiciales dictadas en los Estados miembros instaurado por el Reglamento, principio que se basa en el principio de confianza mutua entre los Estados miembros.

191. $2^{\mathrm{a}}$ ) Si un cambio de circunstancias como la integración de un menor en su nuevo entorno fuera suficiente para autorizar a un órgano jurisdiccional no competente para conocer sobre el fono a adoptar una medida provisional que modifique la medida en materia de responsabilidad parental adoptada por el órgano jurisdiccional competente para conocer del fondo, la posible lentitud del procedimiento de ejecución en el Estado miembro requerido contribuiría a crear las circunstancias que permitirían al primer órgano jurisdiccional impedir la ejecución de la resolución judicial declarada ejecutiva.

192. $3^{\mathrm{a}}$ ) El art. $20 \mathrm{RB}$ II bis no puede interpretarse de modo que viole los derechos fundamentales del menor enunciados en el art. 24 de la Carta de Derechos Fundamentales de la Unión Europea, entre los que se encuentra el derecho del menor "a mantener de forma periódica relaciones personales y contactos directos con su padre y con su madre, salvo si son contrarios a sus intereses". A este respecto debe señalarse que el traslado ilícito de una menor, como consecuencia de una decisión adoptada unilateralmente por uno de sus progenitores, priva a menudo a dicho menor de la posibilidad de mantener de forma periódica relaciones personales y contactos directos con el otro progenitor.

193. $4^{\mathrm{a}}$ ) El art. 20 RB II bis no puede interpretarse de modo que pueda servir de instrumento al progenitor que ha trasladado ilícitamente al menor con el fin de prolongar la situación de hecho creada por su comportamiento ilícito o de legitimar los efectos de dicho comportamiento. Una interpretación así sería contraria al objetivo del Reglamento, que es evitar los traslados o retenciones ilícitos de menores entre Estados miembros

194. $5^{\text {a }) ~ E l ~ a r t . ~} 20$ RB II bis debe interpretarse en el sentido de que "no permite que un órgano jurisdiccional de un Estado miembro adopte una medida provisional en materia de responsabilidad parental que otorgue la custodia de un menor que se encuentra en el territorio de dicho Estado miembro a uno de los progenitores cuando un órgano jurisdiccional de otro Estado miembro, competente en virtud del mencionado Reglamento para conocer del fondo del litigio sobre la custodia del menor, ya ha dictado una resolución judicial que concede provisionalmente la custodia de dicho menor al otro progenitor y esta resolución judicial ha sido declarada ejecutiva en el territorio del primer Estado".

\section{Competencia para conocer de cuestiones incidentales relacionadas con la responsabilidad pa- rental}

195. El RB II ter pone fin a las normas de competencia en materia de responsabilidad parental con una nueva norma, el art. 16, inexistente en el RB II bis, referida a la competencia para conocer de cuestiones incidentales relacionadas con esta materia. 
196. Así, de conformidad con el apartado 1 del art. 16 RB II ter, los órganos jurisdiccionales de un Estado miembro que estén conociendo de un procedimiento en una materia no perteneciente al ámbito de aplicación del Reglamento, tendrán competencia para conocer y resolver una cuestión incidental relacionada con la responsabilidad parental de la que dependa el resultado del procedimiento, aun cuando dicho Estado miembro no sea competente en virtud del presente Reglamento. Por cuestión incidental debe entenderse toda aquella que requiere de una decisión específica y distinta de la que resuelve sobre el objeto principal del proceso, por suscitarse sobre asuntos relacionados con dicho objeto. Así, por ejemplo, si en un procedimiento en materia de sucesiones que afecta a un menor es preciso designar un tutor ad litem para que represente al menor en el marco de ese procedimiento, el Estado miembro competente para conocer del litigio en materia de sucesiones -como regla, el de la residencia habitual del causante- también tiene competencia para designar a dicho tutor para el procedimiento pendiente, con independencia de que sea o no competente para las cuestiones de responsabilidad parental el virtud del presente Reglamento ${ }^{102}$.

197. De conformidad con el apartado 2 del art. 16.2 RB II ter, la decisión sobre la cuestión incidental relacionada con la responsabilidad parental "solo tendrá efecto en el procedimiento en cuyo marco se haya dictado", es decir, no tendrá fuerza de cosa juzgada, dejando a salvo el derecho de las partes de debatir y resolver dicha cuestión ante los órganos jurisdiccionales del Estado miembro que sean competentes para su resolución.

198. El art. 16 RB II ter termina con una disposición relativa a una cuestión incidental específica suscitada en el marco de un procedimiento de sucesión. En algunos casos, la validez de un acto jurídico realizado o que vaya a realizarse en nombre de un menor en un procedimiento de sucesión -p.ej. la aceptación o la renuncia de una herencia o un acuerdo entre las partes sobre la partición o la distribución del patrimonio- requiere la autorización o la aprobación de un órgano jurisdiccional. De ser así, el apartado 3 del art. 16 RB II ter atribuye competencia para decidir si autoriza o aprueba el acto jurídico al órgano jurisdiccional del Estado miembro en el que se está tramitando el procedimiento de sucesión, aun cuando no sea competente en virtud del presente Reglamento.

199. Finalmente, el apartado 4 del art. 16 RB II ter prevé la aplicación del deber de información previsto en el art. 15.2 en materia de medidas provisionales. Así, en la medida en que el interés del menor lo exija, el órgano jurisdiccional que haya decidido la cuestión incidental debe informar sin demora al órgano jurisdiccional o a la autoridad competente del Estado miembro competente para conocer de la materia de responsabilidad parental, ya sea directamente o por conducto de las autoridades centrales designadas.

\section{Comprobación de la competencia}

200. Para garantizar la aplicación efectiva del Reglamento y conforme al principio de la confianza mutua en el que se basa, corresponde a cada órgano jurisdiccional verificar su competencia. Si el órgano jurisdiccional de un Estado miembro considera que, con arreglo al presente Reglamento, carece de competencia para conocer del fondo del asunto y que una autoridad de otro Estado miembro es competente en cuanto al fondo, debe declarar de oficio que no es competente (art. 18 RB II ter) ${ }^{103}$.

201. Preguntado el TJUE si el órgano jurisdiccional, además de declararse incompetente, debe remitir el asunto al órgano jurisdiccional del otro Estado miembro, el Tribunal ha declarado lo siguiente: "el órgano jurisdiccional de un Estado miembro, en el supuesto de que carezca de toda competencia, deberá declararse de oficio incompetente sin estar obligado a remitir el asunto a otro órgano jurisdiccional. Sin

${ }^{102}$ Cfr. Considerando 32 RB II ter.

${ }^{103} \mathrm{El}$ art. $18 \mathrm{RB}$ II ter se corresponde con el art. 17 RB II bis, según la tabla de correspondencias que figura en el Anexo X. 
embargo, siempre que la protección del interés superior del menor lo exija, el órgano jurisdiccional nacional que se haya declarado de oficio incompetente deberá informar de ello al órgano jurisdiccional competente de otro Estado miembro directamente o por conducto de la autoridad central designada (...)"104.

\section{Conclusión}

202. Por lo que se refiere a la competencia judicial internacional en materia de responsabilidad parental, el nuevo Reglamento (UE) 2019/1111 consigue el objetivo perseguido y anunciado por el legislador europeo en el primero de los considerandos, consistente en refundir el actual Reglamento (CE) n'. 2201/2003 "en aras de la claridad". Y es que, aunque el nuevo Reglamento mantiene en esencia el complejo sistema de foros de competencia judicial internacional de su predecesor, prácticamente todas sus normas ganan en claridad expositiva.

203. La Sección 2 del Capítulo II del nuevo Reglamento (arts. 7 a 16) está dedicada íntegramente a la competencia en materia de responsabilidad parental. Se mantiene como foro general el de la residencia habitual del menor, así como el resto de foros del Reglamento (CE) $n^{\circ}$. 2201/2003. No obstante, esta Sección ha sido reestructurada para incorporar en ella la norma de competencia para la adopción de medidas provisionales o cautelares por tribunales no competentes para conocer del fondo del asunto (art. 15), que en el actual Reglamento (CE) $n^{\circ}$. 2201/2003 se halla comprendida dentro de las Disposiciones comunes. Con este cambio, esta norma de competencia deja de ser aplicable a la materia matrimonial y queda reservada en exclusiva a la responsabilidad parental.

204. Aunque algunos de los foros de competencia se mantienen intactos, en otros se han introducido modificaciones importantes. Así, cabe destacar que el nuevo art. 10, a diferencia del art. 12 del Reglamento (CE) n $n^{\circ}$. 2201/2003, no condiciona ya en absoluto la elección de foro a la existencia de un procedimiento conexo pendiente ante los tribunales del Estado miembro elegido por las partes, ni matrimonial ni de ningún otro tipo, incorporándose así la jurisprudencia del TJUE sobre este, hasta ahora, controvertido asunto. Por otra parte, en este precepto se incluye también la exigencia de que el tribunal, antes de asumir su competencia, se asegure de que todas las partes han sido informadas de su derecho a impugnar la competencia. Solo en ese caso se entenderá "aceptada expresamente" la competencia a los efectos de esta norma. Se añade, además, que la competencia fundada en este foro se ejercerá con carácter exclusivo.

205. El actual art. 15, en el que se regula el forum non conveniens, se ha desdoblado en dos preceptos (arts. 12 y 13 en el nuevo Reglamento), con lo que se consigue aportar claridad a este foro. En el art. 12 se regula la remisión de competencia a un órgano jurisdiccional de otro Estado miembro reputado conveniens de oficio o a instancia de parte, y en el art. 13 la transferencia de competencia a petición de un tribunal de otro Estado miembro. Además, en caso de que la remisión se efectúe de oficio o a petición de un tribunal de otro Estado miembro se suprime la exigencia actual del consentimiento de al menos una de las partes.

206. En relación con la adopción de medidas cautelares por un tribunal no competente para conocer del fondo del asunto, se establece de forma expresa el deber de informar sin demora de la medida adoptada al órgano competente, siempre que la protección del interés del menor lo exija. Por último, el Reglamento introduce una nueva norma de competencia para resolver cuestiones incidentales relacionadas con la responsabilidad parental.

207. En positivo, hay que destacar también que el nuevo Reglamento incorpora en muchos de sus considerandos las declaraciones efectuadas por el TJUE en estos más de 15 años de vigencia del actual Reglamento sobre el sentido en que han de interpretarse sus normas de competencia.

${ }^{104}$ STJUE de 2 de abril de 2009, A, C-523/07). 
208. No obstante las mejoras introducidas, el Reglamento sigue sin dar respuesta a algunas cuestiones. Entre otras, sigue sin resolverse si el foro de elección del órgano jurisdiccional del nuevo art. 10 resulta aplicable aun cuando el menor tenga su residencia habitual en un tercer Estado. Nada se dice, tampoco, sobre la posibilidad de remitir la competencia en favor de un tribunal de un tercer Estado, lo que genera una considerable incertidumbre, sobre todo, en relación con terceros Estados que no son parte contratante del Convenio de La Haya de 1996, tal y como señaló la Comisión en su Informe sobre la aplicación del Reglamento (CE) $n^{\circ}$. 2201/2003. Y, puestos a echar en falta, hay que señalar que el nuevo Reglamento en materia de responsabilidad parental, a diferencia de los más recientes instrumentos comunitarios en materia de Derecho de familia, no contiene un forum necessitatis. 